\title{
Boğaziçi Bebek Semti Tarihi ve Yapıları
}

\author{
* \\ Sezgi Giray Küçük ${ }^{1}$ \\ ORCID: 0000-0002-4556-4331
}

\section{Öz}

Bir yerleşimin tarihini yapıları üzerinden okumak mümkündür. Tarihte yaşanan değişim ve gelişimlere bağlı olarak kentteki yapılar da çeşitlenir, ihtiyaca binaen farklı yapı tipleri ortaya çıkar. Bu çalışma, İstanbul'un Rumeli yakasındaki Boğaziçi semtlerinden Bebek'in tarihsel gelişimini, bu gelişim sürecinde inşa edilen, yıkılan ve dönüşen yapıların yazılı ve görsel arşiv belgeleri üzerinden değerlendirmeyi, bu bağlamda İstanbul'un tarihine katkıda bulunmayı amaçlamaktadır. Devlet Arşivleri belgeleri, eski haritalar gibi bu bölge için daha önce ele alınmamış kaynaklar kullanıldığından, çalışma özgün nitelik taşımaktadır. 16. yüzyılda, Osmanlı padişahlarının sayfiye yerlerinden biri olan Bebek'teki en önemli yapı, Bebek (Hümayûnâbad) Kasrı olmuştur. 17. ve 18. yüzyıllarda Bebek'in sahil kısmına yahlar inşa edilmeye başlanmış, 18. yüzyılın ilk çeyreğinde cami, mektep, hamam ve çarşı ile tipik bir Osmanlı mahallesi olan Bebek Mahallesi kurulmuştur. 19. yüzyılda Tanzimat ve Islahat fermanlarının getirdiği yeniliklerle, ulaşım, haberleşme, savunma yapıları, gayrimüslimlere ait dini yapılar ve eğitim yaptları Bebek'te yer almıştır. Zaman içinde, değiş̧en devlet ve şehircilik politikaları, gelişen teknoloji gibi sebeplerle bölgedeki yapı çeşitliliği azalmış olup günümüzde bölge, çoğunlukla eğlence sektörüne ait mekânlardan ve konutlardan oluşan, İstanbul'un elit semtlerinden biridir. Mevcut tarihi yapılarının korunması, Bebek'in kentsel belleği açısından büyük önem taşımaktadır.

Anahtar Kelimeler: Boğaziçi, Bebek, yapılar.

${ }^{1}$ Dr. Öğr. Üyesi, Mimar Sinan Güzel Sanatlar Üniversitesi, Meslek Yüksek Okulu, Mimarlık ve Şehir Planlama Bölümü, Mimari Restorasyon Programı. E-mail: sezgi.giray.kucuk@msgsu.edu.tr 


\title{
Bosphorus Bebek District's History and Buildings
}

\author{
Sezgi Giray Küçük ${ }^{2}$ \\ ORCID: 0000-0002-4556-4331
}

\begin{abstract}
It is possible to read the history of a settlement through its structures. This study evaluates the historical development of Bebek, one of the Bosphorus districts on the Rumeli side of Istanbul, and the structures that were built, destroyed and transformed in this development through written and visual archive documents. The most important building in Bebek, which was used as a summer resort by the Ottoman sultans in the 16th century, was the Bebek (Hümayûnâbad) Pavilion. In the 17th and 18th centuries, mansions began to be built on the coast. In the first quarter of the 18th century, Bebek District, a typical Ottoman district, was established with a mosque, school, Turkish bath and bazaar. With the innovations brought by the Tanzimat and Islahat edicts in the 19th century, transportation, communication, defense structures and religious and educational structures belonging to non-Muslims were located in Bebek. Over time, the diversity of buildings has decreased due to the changing state and urban planning policies. Today, Bebek is one of the elite districts of Istanbul, mostly consisting of entertainment sector venues and residences. Conservation of existing historical structures is of great importance for Bebek's urban memory.
\end{abstract}

Keywords: Bosphorus, Bebek, buildings.

\footnotetext{
${ }^{2}$ Assist. Prof. Dr., Mimar Sinan Fine Arts University, Vocational School, Architecture and City Planning Department, Architectural Restoration Programme. E-mail: sezgi.giray.kucuk@msgsu.edu.tr
} 


\section{Giriş}

Geçmişten günümüze pek çok uygarlı̆̆a ev sahipliği yapmış olan İstanbul, günümüze ulaşabilen tarihi yapılarının oluşturduğu geleneksel mimarisiyle adeta bir hazine niteliğindedir. İstanbul ile ilgili çok sayıda araştırma yapılmış olmasına rağmen aydınlanmayı bekleyen daha pek çok belge vardır. Kuban'ın (1996, s.xiv) dediği gibi Türk dönemi İstanbul'unun kentsel tarihi henüz yazılmamıştır.

İstanbul'un simgelerinden Boğaziçi, tarih boyunca kent dışı yaşam, avcllık ve balıkçılık için oldukça cazip bir doğal çevreye sahip olmuştur. Bizans döneminde bu kıyılarda küçük balıkçı köyleri kurulmuş, Boğaz köylerinde inşa edilen en erken tarihli yapılar, soyluların kent dışı villaları olmuştur. Zaman içinde burada kilise ve manastırlar da inşa edilmiştir (Kuban, 1996, s.110). Osmanlı Türklerinin Boğaziçi'ne ilgisi ise henüz İstanbul fethedilmeden, buranın askerî önemini kavrayarak Anadolu ve Rumeli Hisarları'nın inşa edilmesi için tahkimat yapmalarından anlaşılmaktadır (Gökbilgin, 1992, s.251). Fetih sonrası Rumeli Hisarı'nın inşası sırasında asayişi sağlamakla görevli yeniçeri ağası bölükbaşı Bebek Çelebi, Rumelihisarı'nın yanındaki yerleşim olan Bebek'te kendisi için bir köşk ve bahçe inşa ettirmiş olup, Çelebi'nin vefatından sonra yerleşim Bebek olarak anılmıştır. Yerleşimin Bizans dönemindeki ismi ile ilgili farklı görüşler vardır. Gökbilgin (1992, s.254), Bebek'teki sahil boyunca bulunan ve yolcuların karaya ve tepelere çıkmasını kolaylaştırmak amacıyla yapılmış olan basamaklardan dolayı yöreye Hélai veya Echelé dendiği söylemektedir. Ancak Eyice (1976) bunun doğru olmadığını iddia etmekte, Khalei'nin Bebek değil, Boğaz'nn yukarı ucunda bir yer, büyük ihtimalle Şile olduğunu ileri sürmektedir.

Bebek'in tarihine ve Osmanlı döneminden başlayarak burada yer almış yapılara ışık tutan bu makaleyle, Bebek'in tarihî gelişiminin, yapıları üzerinden okunması amaçlanmaktadır. Çalışma alanı olarak Bebek'in seçilmesinin nedeni, günümüzde İstanbul'un en eski ahşap yapılarından olan Kavafyan Köşkü gibi pek çok kıymetli tarihi yapıyı barındırmasına rağmen üzerinde fazla araştırma yapılmamış bir bölge olmasıdır. Çalışma çerçevesinde, İstanbul'un tarihi ve zaman içerisindeki değişimi ile ilgili yayınlardan (Çelik, 1996; İnciciyan, 1976; Kuban, 1996), Boğaziçi'nin geneli hakkında bilgi veren (Deleon, 1998; Gökbilgin, 1992; Şehsuvaroğlu, 1986) veya köylerini tek tek ele alan yayınlardan (Germiyanoğlu, 1961; Gökbilgin, 1992), Bebek veya içerisindeki yapı işlevleri özelinde yazılmış kitap ve makalelerden (Eldem, 1993; Galitekin, Ayvansarayî, Ali, Süleyman, 2001; Kayra, 1993; Kayra ve Üyepazarc1, 
1992), çeşitli ansiklopedi maddelerinden, haritalardan, eski fotoğraf, gravür ile kartpostallardan ve kişisel arşivlerden yararlanılmıştır. Ancak çalışmanın esas kaynağı, Osmanlı ve Cumhuriyet Arşivlerinin yer aldığı Devlet Arşivleridir. Bu çalışmayı benzer çalışmalardan ayıran, bugüne kadar ele alınmamış arşiv belgelerini değerlendirmesi olmuştur. Bebek ve eski ismi olan Hümayûnâbâd kelimeleriyle Devlet Arşivlerinde yapılan taramada tespit edilen belgeler tasnif edilip değerlendirilerek, dönem ve yapıların işlevlerine göre sınıflandırılmış, kronolojik olarak geçmişten günümüze aktarılmaya çalışılmiştır.

\section{6. ve 17. Yüzyıllarda Bebek ve Yapıları}

Osmanlı sultanları, idare merkezi olan esas sarayların yanı sıra, yaz aylarını geçirmek, dinlenmek ve eğlenmek amacıyla farklı yerlerde saraylar, kasırlar, köşkler inşa ettirmişlerdir. Bunun için topografyası ve iklim özellikleriyle özel bir mekân olan Boğaziçi köylerini sıkça tercih etmişlerdir. Bebek'teki kasır da bu süreçte inşa edilen kasırlardandır. Bu dönemde Boğaziçi'nde yerleşim özendirilmiş, zaman içinde yavaş ama düzenli bir nüfus artı̧̧ı meydana gelmiştir. 16. yüzyılda İstinye, Üsküdar, Yeniköy gibi bazı Boğaz köylerinde Türk mahalleleri oluşturulmuş olsa da Bebek'te çoğunlukla Rum yerleşimi mevcut olup semtte Türk mahallesi 18. yüzyılda kurulmuştur (Kuban, 1996, s.255).

\section{Bebek (Hümâyunâbâd) Kasrı ve Bahçesi, 16. yüzyıl}

İnşa edildiği 16. yüzyıldan yıkıldığı 19. yüzyıla kadar Bebek'in simgesi olmuş en önemli yapısı Bebek Kasrı ve ulu çınarlarıyla ünlü has bahçesidir. Bebek Kasrı, Yavuz Sultan Selim (1512-1520) tarafından 16. yüzyılda küçük bir kasır olarak inşa edilmiş, yıllar içerisinde bakımsız kalarak harabeye dönüşmüştür (Koçu, 1961d, 2337). Lale Devri'nde (1718-1730), Sultan III. Ahmed'in veziri damat Nevşehirli İbrahim Paşa tarafından ve daha sonra Cezayirli Gazi Hasan Paşa tarafından yeniden inşa ettirilmiştir (1774-1789). Sultan III. Selim döneminde (1789-1807) kasır son kez yenilenmiştir ("Sermimaran-1 hassa", 1203; Koçu, 1961d, s.2338) (Şekil 1). Devlet Arşivlerindeki Bebek Kasrı ve Bahçesi ile ilgili belgeler 1531-1914 yılları arasına tarihlenmekte olup çoğu 18. ve 19. yüzyıllara aittir. Bu belgeler, kasır ve bahçesinde yapılan görüşmeler, törenler, kandil tebriki, kasırdaki eşyalar, çalışanlar, kasrın tamiri, bahçede yetiştirilen meyveler gibi farklı konulara ilişkindir. Osmanlı döneminde, İngiltere, Fransa, Rusya gibi ülkelerin elçileriyle önemli uluslararası görüşmeler yapıldığından kasra Konferans Sarayı da denmiştir (Şehsuvaroğlu, 1986, s.147). Yapılan görüşmelerle ilgili 
Osmanlı Arşivindeki belgeler 1790-1828 yılları arasına tarihlenmektedir. 1835 yılında kenti ziyaret eden Miss Pardoe da bu yapının gizli görüşmeler için kullanıldığından, dikkat çekmemesi için özellikle bakımsız bırakıldığını belirtmiştir (Şehsuvaroğlu, 1986, s.143). Biniş Yeri (Şehsuvaroğlu, 1986, s.9) olarak da anılan Bebek Kasrı'nın 19. yüzyılda önce bahçe duvarları, sonra Sultan Abdülmecid'in emriyle tamamı yıktıılmıştır. 17. yüzyılda çok da bakımlı olmayan ancak yüksek selvi ağaçlarıyla dikkat çeken (Kahraman ve Dağlı, 2011, s.414), 18. yüzyılda tüfek talimlerinin, müzikli eğlencelerin ve yarışmaların yapıldığı kasrın bahçesi ise 1908'de II. Meşrutiyetin ilanı sonrası Millet Bahçesi adıyla halka açılmış, 20. yüzyılın ikinci yarısında başbakan Adnan Menderes döneminde içerisinden yol geçirilerek küçültülmüştür. Bahçe günümüzde Bebek Parkı olarak kullanılmaktadir.

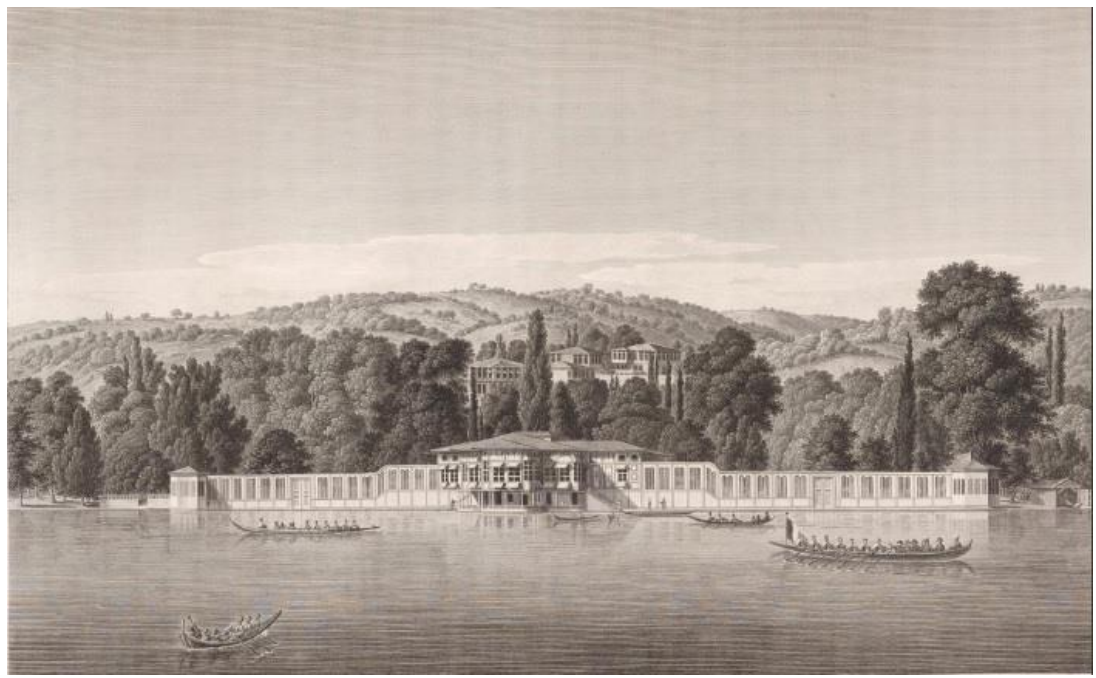

Şekil 1. Bebek Kasrı gravürü (Kaynak: Melling, 1819)

\section{Durmuş Dede Tekkesi/Zaviyesi/Dergâhı, 16. yüzyıl}

Durmuş Dede Tekkesi, Kanuni Sultan Süleyman zamanında (1520-1566) Misur'dan İstanbul'a gelmiş olan Şeyh İbrahim Gülşenî halifelerinden Hasan Zarîfî Efendi (ö.1569) tarafindan kurulmuş, Durmuş Dede'nin burayı ziyareti sonrası Durmuş Dede Dergâhı olarak anılmaya başlanmıştır (Koçu, 1968, s.4770). Germiyanoğlu (1961, s.2328), Şakaaik Zeyli Atâî'nin, 1529'dan önce bu tekkenin kurulmuş olduğunu söylediğini belirtmektedir (Germiyanoğlu, 1961, s.2328). Dolay1sıyla 1520-1529 yılları arasında yapılmış olmalıdır. Osmanlı döneminde, donanmalar denize açlmadan önce hava hakkında yorum yaparak yol göstermesiyle 
meşhur, tekkeye ismini veren Durmuş Dede, 1616 yllında vefat etmiştir (Kayra, 1993, s.48).

Geçmişten günümüze, Türk şehirlerinin kuruluş ve gelişmesinde, halkın dini inançlarının temsilcisi olan dervişlerin etkisi büyük olmuştur. Osmanl1ların erken devirlerinde, derviş zaviyeleri, birçok köyün çekirdeğini teşkil etmiş ve bu dervişler kolonizatör olarak görev yapmıştır. Şehirlerde bir şeyhin zaviyesi etrafında meydana gelen mahalleler oldukça fazladır. Mescidin, ev ve ahırların da inşa edilmesiyle halk bu zaviyelerin etrafına yerleşmeye başlamıştır (Kuban, 1968, s.60). Planlı mahalle/köy oluşumu 18. yüzyıl başında olan Bebek'te ilk yerleşimin bu tekkenin etrafında kurulduğu düşünülmektedir. Evliya Çelebi'nin, 17. yüzyılda Bebek'te Sıdkı Efendi Camisi'nin etrafında kırk elli hanenin olduğunu söylemesi bunu doğrulamaktadır (Kahraman ve Dağll, 2011, s.414).

\section{Kayalar Mescidi (Sıdkı Ahmed Efendi Mescidi) ve Çeşmesi, 17. yüzyıl}

Adını bulunduğu mevkiden alan bu mescit, 17. yüzyılın ikinci çeyreğinde Nişana Sıdkı Ahmet Paşa (ö.1662) tarafindan yaptırlmıştı. Evliya Çelebi, caminin fevkani olduğunu belirtir ve şöyle der: "Caminin altında kayadan tath bir pınar kaynar" (Kahraman ve Dağlı, 2011, s.414). Zaman içinde kârgir duvarlı ve ahşap çatılı olduğu bilinen ilk yapı ortadan kalkmış yerine 1877' de Kâdirî tarikatına bağlı Şeyh Ahmed Niyazi Efendi Tekkesi, Kayalar Tekkesi veya Ahmed Sıdkı Efendi Tekkesi isimleriyle bilinen iki katlı, ahşap çatlı bu bina inşa edilmiş, 1893'te minaresi onarılmıştır ("Bebek'de Kayalar", 1311). Haziresinde Şeyh İsmail Maşuki gömülüdür ("Envanter", t.y.b). 1925'te tekkelerin kapatilması sürecinde kapanmıs, bakımsız kalmış, daha sonra hayırseverlerin yardımlarıyla onarılmış ve 1987'de cami olarak ibadete açılmıştır (Dişören, 1995, s.498) Günümüzde hala bu işlevle kullanılmaktadır (Şekil 2). Yılanlı Yalı'nın sahibi Reisülküttab Mustafa Efendi tarafından (Kayra, 1993, s.51), 1763'te Kayalar Mescidi'nin altına bir çeşme yapılmıştır (Galitekin vd., 2001, s.118). Ancak bu çeşme, 1914'te Cevdet Paşa Caddesi düzenlemeleri sırasında yıkılmıştır (Germiyanoğlu, 1961, s.2328).

\section{Veziriazam Mesih Paşa Vakıfları Odalar, 1637}

Devlet Arşivlerinde yer alan Bebek ile ilgili en eski tarihli belgeye göre (1637), Bebek yokuşunda Veziriazam Mesih Paşa vakıfları olan odalar yer almaktadır ("Akarat", 1046). Bu odalar ile ilgili başka bir bilgi elde edilememiştir. 


\section{Yüzyılda Bebek Köyü'nün Gelişimi ve Yapıları}

Osmanlı Devleti'nin 18. yüzyılda her alanda yeni arayışlar içerisine girdiği görülmektedir. Bunun sebebi, imparatorluğun siyasî, askerî, iktisadî ve sosyal olarak içinde bulunduğu bunalımlı vaziyet ve Batı'nın sömürgeler çağg ile birlikte iktisadî ve askerî olarak önlenemez yükselişiydi. Artık fetihler devri bitmiş, bozulan tımar sistemi neticesinde şehirlere göç artmış ve bu durum, tarımdaki üretimin düşmesine neden olmuştur. Yaşanan tüm bu gelişmeler karşısında, kötü gidişatı durdurmak için Osmanlı idarecileri bir reform süreci başlatmış; askerî ve iktisadî alanlarda yeni düzenlemeler yapmışlardır. Ancak sadaret makamında ve diğer önemli mevkilerde bir düzenin sağlanamaması, çok sık el değiştirmelerin yaşanması yüzünden bu düzenlemelerden istenen verim alınamamıştır. Klasik Osmanlı devrinde İstanbul şehri idarî açıdan dört kadılığa ayrılmıştır. Bunlar, İstanbul (Nefs-i İstanbul, suriçi), Galata, Üsküdar ve Eyüp kadılıklarıdır. 18. yüzyılda, Galata ve Üsküdar kadılıklarına bağlı olan Boğaziçi'nde yerleşim artmıştır. Ayrıca bu yüzyılda Boğaziçi'ndeki küu̧ük camilerle mescitlerin ve karşı kıyıya geçmede kullanılan pereme adı verilen kayıkların da sayısının arttığı gözlemlenmektedir (Ağaoğlu, 2018, s.90).

Bebek de bu yüzyılda yapılaşmaya açılarak cami, mescit gibi çeşitli yapılarla donanmıştır. Etrafındaki Boğaz köylerinde yaşam varken Bebek'in kullanılmıyor oluşu ve Bebek Kasrı'nın uzun yıllar bakımsız kalması sebebiyle uygunsuz davranışların icra edildiği bir mekân haline gelmesi, Sadrazam Nevşehirli İbrahim Paşa'nın dikkatini çekmiş, Salih Paşa'yı görevlendirerek Hicri 1138, Miladi 1725-1726 yılında Bebek Kasrı'nı yenilemiş, yanına da cami, çarşı ve bir hamam yaptırmıştır. Bunu takiben, Küçük Bebek tarafındaki Kayalar mevkiine kadar sahilde olan ve kara tarafındaki mirî (devlete ait) arazi parsellenerek halka satılmıştır. Birkaç ay içinde burada yeni bir Boğaz köyü/mahalle kurulmuş ve bu köye Hümâyun-âbâd denmiştir. Bunun yanında Bebek ismi de kullanılmaya devam edilmiştir (Koçu, 1961d, s.2337). Bu oluşum, Osmanlı dönemi mahalle kuruluşu ile paralellik göstermektedir. Osmanlı döneminde mahallenin merkezi, yakınında imamin evi bulunan mescit/cami olmuş, mektep, caminin içinde yer almıştır (Kuban, 1968, s.67).

\section{Bebek (Hümâyûnâbâd) Camisi ve Çeşmesi, 1725}

1725 yllında Bebek Mahallesi kurulurken inşa edilen Bebek Camisi fevkâni olarak tasarlanmış, alt kotuna mektep inşa edilmiştir. Minarenin altında 1138 tarihli çeşmesi (Miladi 1735/1736), karşısında hamamı ve cami çalışanlarına ait meşrutaları mevcuttur (Galitekin vd., 2001, s.528). Arşivlerde 
Sultan I. Ahmed Camii ve Hümâyûnâbâd Camii isimleriyle de görülen caminin tamiri, bütçesi, vakıfları, camide yapılan törenler gibi konularda 17431939 yılları arasına tarihlenen belgeler mevcuttur. Arşiv belgelerinin 13'ünde caminin Sultan II. Mahmud, ikisinde Sultan III. Ahmed, ikisinde Sultan I. Ahmed Vakfı'na ait olduğu belirtilmiştir. 1796 tarihli Osmanlı Arşivi belgesine göre Bebek Camisi'nin vakıfları arasında Nazlıca Köyü'nde bir mescit ("Nakibüleşraf", 1211), 1832 tarihli bir başka belgeye göre bir sahilhane vardır ("Asakir-i", 1247). Bebek Camisi, arşiv belgelerinden görüldüğü üzere 18641901 yılları arasında çok kez tamir edilmiştir. Cami Mustafa Hayri Efendi'nin Evkaf Nazırlığı döneminde yıkılmış olup 1912'de Birinci Ulusal Mimarlık Akımı'nın önde gelen isimlerinden Mimar Kemaleddin tarafından yeni bir cami yapılmıştır (Göktürk, 1961a, s.2332) (Şekil 2).

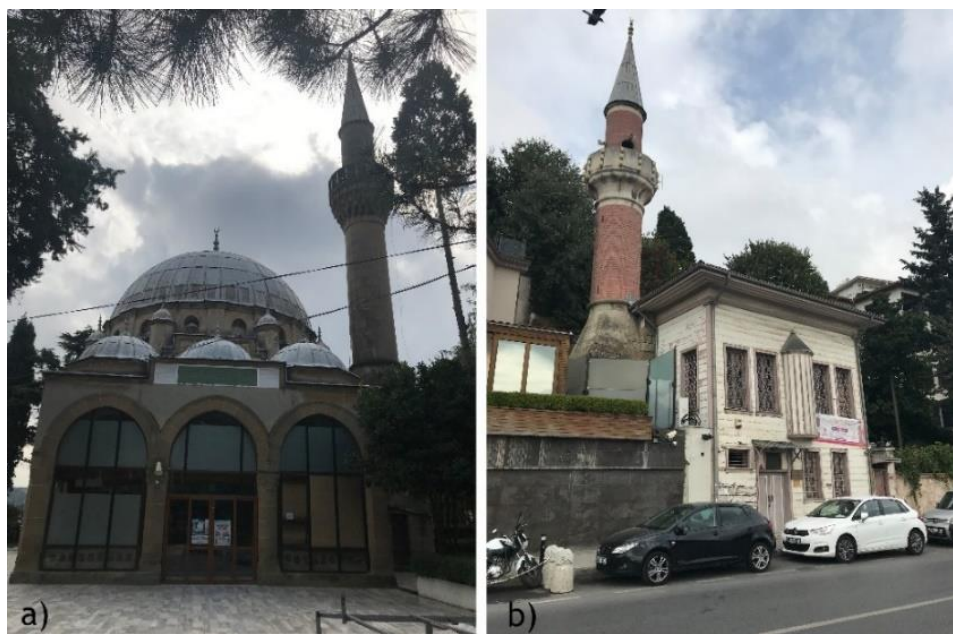

Şekil 2. Günümüzde a) Bebek Camisi, 2019 b) Kayalar Mescidi, 2019

(Kaynak: yazarın fotoğraf arşivi)

\section{Bebek Camisi Meșrutahaneleri (Lojmanları)}

1904 tarihli haritada, caminin karşısındaki dükkanların arkasında imam, müezzin ve kayyum meşrutahaneleri vardır (Şekil 3a). Arşiv belgelerine göre, 1896 ("Bebek Camii", 1314; “Sultan”, 1314) ve 1905 yıllarında imam ve müezzine ait meşrutahane tamir edilmiştir. Bir başka arşiv belgesinde meşrutaların bulunduğu yapı adasında Şirket-i Hayriye tahsildarı İzzet Efendi'nin ve Aşçı Mustafa Ağa'nın evleri görülmektedir ("Bebek Camii", t.y.) (Şekil 3b). Meşrutalar, 1957-1958 arasında Bebek meydanı genişletilirken yıkılmıştır (Göktürk, 1961a, s.2333). Günümüzde Bebek Camisi avlusu içinde bir meşrutahane mevcuttur. 

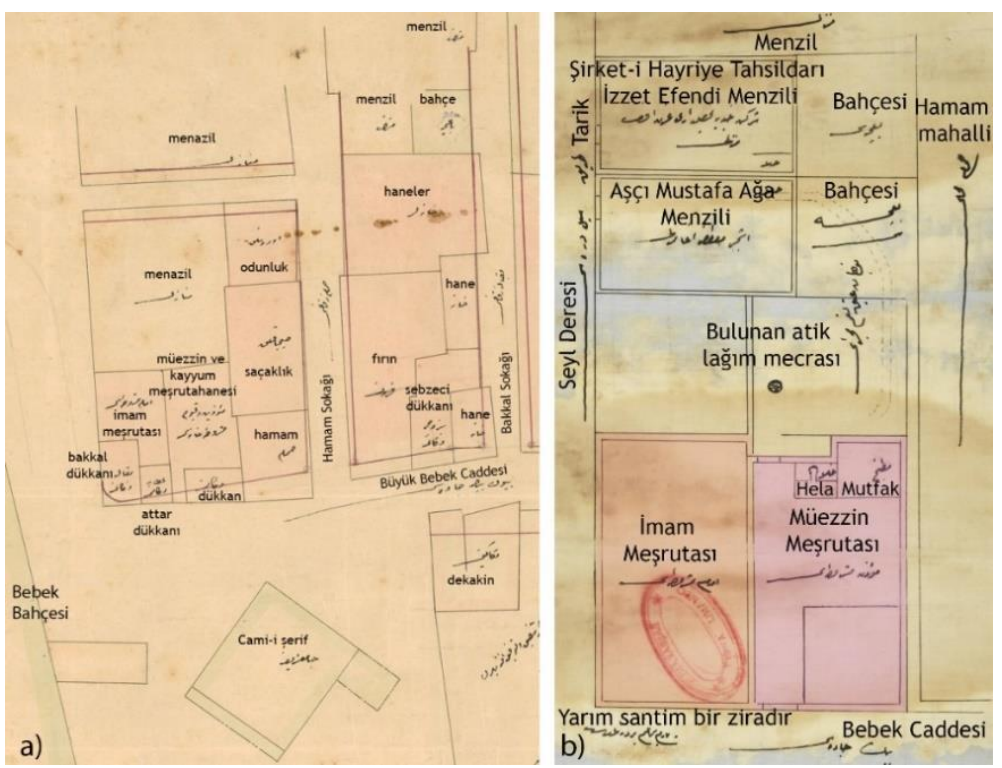

Şekil 3. a) 1904'te Bebek'te yapılar ve işlevleri (Kaynak: “Beşiktaş-Bebek vapur”, 1320) b) Tarihi belirtilmemiş imam ve müezzin meşrutaları planı (Kaynak: “Bebek Camii”, t.y.).

\section{Bebek (İbtidai) Mektebi, 1725}

Caminin alt katında yer alan okul, 1876-1909 yılları arasına tarihlenen Osmanlı Arşivi belgelerinde Bebek İbtidai Mektebi veya III. Ahmed Mekteb-i İbtidaiyesi olarak geçmektedir. İlköğretim seviyesinde eğitim verilen ibtidai mektepleri, Tanzimat öncesinde sıbyan mektepleri olarak anılmaktayken, Tanzimat'tan sonra II. Abdülhamit döneminde mekteb-i ibtidailere dönüşmüştür (Baltacı, 2004, s.6). Tanzimat dönemi nizamnamelerinden biri olan 1869 Maarif Nizamnamesi ile tüm köy ve mahallelerde kurulmuştur (Akyüz, 2012, s.160). Arşivdeki belgeler, okulun gelirinin arttırılması, okulda çıkan hastalıklar, öğretmenler, öğrenciler ve çalışanlar ile ilgilidir.

\section{Bebek Hamami, 1725}

1725 yılında Bebek Mahallesi kurulurken inşa edilen Bebek Hamamı, 1730 yılındaki Patrona Halil İhtilali'nden kısa süre sonra, İstanbul hamamlarında çalışan natır, tellak, külhancı ve yanaşma hamam uşakları hakkında düzenlenmiş bir defterde, Bebek Hamamı'nda iki nefer uşak gösterilmiştir. Bu da hamamın ne kadar küçük olduğunun bir kanıtıdır (Göktürk, 1961b, s.2337). 1766 tarihli bir Hamam defterinden de Bebek Hamamı hakkında bazı bilgiler edinmek mümkündür. Bu belgeye göre Bebek Hamamı, kadın ve erkeklerin aynı mekânı farklı zamanda kullandıkları kuşluk türünde bir hamamdır. Bebek Cami-i Şerîf Vakfi'na ait olan hamam, Hala Gümrük Emîni Mehmed Ağa 
ile mastariyeci Hasan Ağazâde Mehmed Ağa'nın tasarrufundadır. Gedik mutasarrıfı, Ahmed Beşe'dir. Gedik kirası 50 kuruş, vakıf kirası 12,5 kuruş olmak üzere toplam kirası 52,5 kuruştur (Yaşar, 2020, s.97). 1904 tarihli haritada görüldüğü üzere, Bebek Camisi'nin karşısındaki yapı adasının köşe parselinde yer almaktadır ("Beşiktaş-Bebek vapur", 1320). Aynı yıl gerçekleşen yangında camekanı yanmıştır ("Beşiktaş-Bebek harik", 1320). Şehremaneti harita şubesi müdürü mühendis Necip Bey'in 1918 tarihli İstanbul Rehberi'nde hamam görülmektedir (Ayyıldız, 1961, s.2330). Hakkı Göktürk'ün görüştügü̈ M. Çelik isimli kişinin verdiği bilgiye göre, 1925 yllında hamam burada mevcut değildir (Göktürk, 1961b, s.2337). Yani 1918-1925 yılları arasında yıkıldığı söylenebilir.

\section{Bebek Çarş1s1, 1725}

Bir Osmanlı Arşivi belgesinde, Bebek çarşı meydanı belirtilmiş olup burada terzi, sobacı, berber, kunduracı, firın gibi dükkânlar görülmektedir (Şekil 4). Bunun yanında 19. ve 20. yüzyıla tarihlenen çeşitli arşiv belgeleri ve haritalardan, Bebek'te mumhane, eczane ("Bebek ecza", 1283), kahvehane ("Bebek'te bulunan", 1321), kasap ("Kasab", 1287) sebzeci, attar, bakkal (Şekil3), sütçü (“Bebek'te sütçü", 1320) gibi dükkanların da var olduğu anlaşılmaktadır.

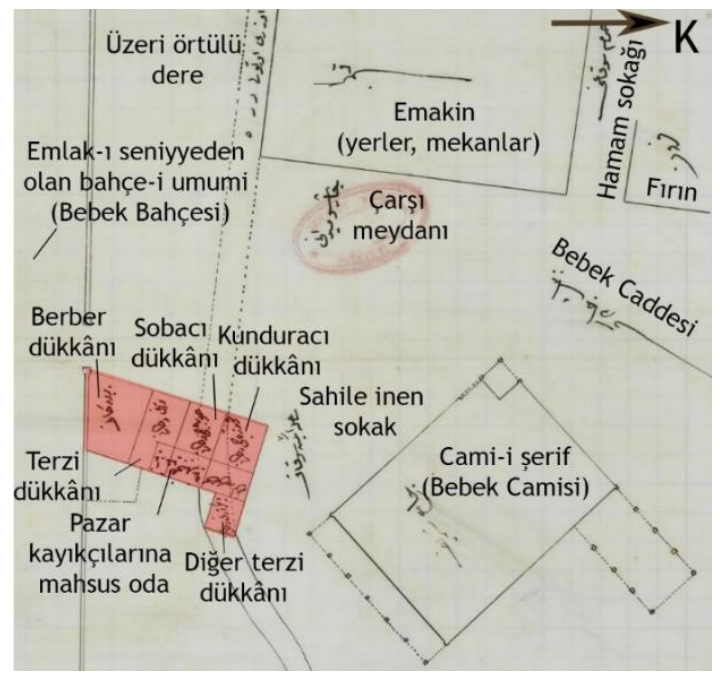

Şekil 4. Bebek Çarşı meydanı ve dükkânlar (Kaynak: “Bebek'teki Hümayun-ı" t.y.).

\section{Bebek Peksimethanesi, 1730}

Tersane-i Amire için peksimetlerin hazırlandığı (Şehsuvaroğlu, 1986, s.142) Bebek Peksimethanesi, 1730 yılında Hacı Nurullah Ağa tarafından vakfedilmiştir (Kayra, 1993, s.30). Peksimethane ile ilgili en eski Osmanlı Arşivi belgesi, 1767 tarihli olup bu belgede, vefat eden peksimetçi başı Salih Ağa'nın 
Bebek'te bir firını olduğu söylenmektedir. 1800 yılında, birden fazla binadan oluştuğu ve Bebek Bahçesi civarında ("Rumeli hisarı", 1214). Hekimbaşı Yalısı'nın yanında bulunduğu bilinmektedir (Germiyanoğlu, 1961, s.2328). Arşiv belgelerinin çoğu peksimethanenin malzeme ödemeleri ve peksimet talebi ile ilgilidir. 1801'de tamir edilmiştir ("Bebek'teki peksimethanenin", 1216). 1830 yılına kadar olan belgelerin büyük kısmı, ilkbaharda çıkacak donanmada çalışan mürettebat için yapılacak olan peksimetin un, buğday ve odunlarının ödemeleri hakkındadır. Peksimethane, 1830 yllına kadar varl1ğını sürdürmüş (Kayra, 1993, s.41), 1831'de çkan yangından sonra kaldırılarak Halıcıŏlu'ndaki Tersane binaları dâhilindeki yeni tesisine taşınmıştır. 1834 'te ise arsası satılmıştır ("Taraf-1", 1249).

\section{Hacı Nurettin/Nurullah Ağa (Peksimetçibaşı) Çeşmesi, 1730}

Bebek-Arnavutköy yolu üzerinde, sahilde yer almış olan Hacı Nurettin Ağa Çeşmesi, 1730 yılında inşa edilmiştir. Bir evin duvarına gömülerek yerleştirilmiş küçük bir mermer ayna taşı ile mermer teknesi vardır. Ayna üzerinde yer alan iki satıllık kitabesinde: "Peksimetçi Elhac Nurettin Ağa, Vakfı hayratının çeşmesidir, Fi Safer 25 sene 1143" yazmaktadır. 1993 yılında çeşme, musluğu koparılmış ve çalışmaz halde iken günümüzde mevcut değildir (Şehsuvaroğlu, 1986, s.142).

\section{Yalılar ve Köşkler}

17. yüzyıldan itibaren ekonomik gelişme gösteren Batılı uluslar, bir yandan Osmanlı Devleti ile ticari ve diplomatik ilişkilerini güçlendirirken, diğer yandan Doğu'ya ve Doğu uygarlıklarına kültürel ve düşünsel bir merak duymaya başlamışlardır. Bu ilginin artması, tüccarlardan sonra sanatkarları, gezginleri ve araştırmacıları da Osmanlı topraklarına çekmiş ve İstanbul'da yabancı nüfusun güçlenmesine yol açmıştır (Batur, 1985, s.1039). Avrupa ülkelerinin ilerlemesinin sonuçları karşısında Batı'yı tanıma ve bunun nedenlerini anlama isteği, Osmanlı Devleti'nde yeni bir dönemin başlangıcı olmuştur. Lale Devri diye tanımlanan, Batı'ya açılmadaki ilk adımların atıldığı bu dönem, 1721 yılında Sultan III. Ahmed (1703-1730) zamanında Yirmisekiz Mehmet Çelebi'nin elçi olarak Fransa'ya gönderilmesiyle birlikte başlamıştır. Fransız kültürünü yakından tanıyan, Batı tarzı yaşamdan oldukça etkilenen Çelebi'nin kaleme aldığı gözlem ve görüşler Osmanlı saray çevresinde geniş yansımalar bulmuştur. Kağıthane Sadabad düzenlemesi ve sonra Haliç ve Boğaziçi kıyılarına inşa edilen batı ilintili saray, yalı ve konaklarla birlikte yaşam biçiminde de bir değişim başlamıştır (Yergün, 2002, s.4,5). 
Bu gelişmelere paralel olarak özellikle 17. ve 19. yüzyıllar arasında Bebek sahilinde çok sayıda yalı inşa edilmiştir. Bu yalıların büyük çoğunluğu devletin yönetiminde rol oynamış sultanlar, paşalar, sadrazamlar ve bunların hekimbaşıları, kaftan ağaları gibi varlıklı insanlara ve şeyhülislam, halife gibi din adamlarına aittir. Sadrazam Yusuf Kâmil Paşa' nın (Kayra, 1993, s.77), Sultan II. Mahmud'un hekimbaşısı Behçet Mustafa Efendi'nin (Şehsuvaroğlu, 1986, s.228) günümüzde Bebek' in sahil caddesine adını da veren Adliye Nazırı Cevdet Paşa'nın, Maarif Nazırı Haşim Paşa'nın yalıları gibi pek çok yalı, 18. ve 19. yüzyılda Boğaz siluetinin şekillenmesinde önemli rol oynamıştır. Bu yalılar genellikle kullanıcılarının isimleriyle anılmış, zaman zaman sahip değiştirmiş veya yıkılıp yeniden yapılmışlardır. Yalılarla ilgili arşiv belgelerinde yalıların sahipleri, tamirleri, kiralama, haciz gibi işlemlerden de söz edilmektedir. Günümüzde, bu yalıların büyük kısmı yıkılmış, bir kısmı yenilenerek günümüze ulaşmıştır. Günümüze ulaşmış olan yalılar/köşkler aşağıda belirtilmektedir.

\section{Kavafyan Köşkü/Evi, 1751}

Kavafyan Köşkü (evi), 1751 yılında Ermeni bir tüccar tarafından yaptırılmıştır (Kayra, 1993, s.43). Yoğurtçu Zülfü Yokuşu üzerinde yer alan köşk, kilisenin yakınında olduğundan saygın bir aileye ait olduğu söylenebilir (Eldem, 1993, s.166). Bebek'teki diğer yalı/evlerden farklı olarak, Boğaz kenarında değil, mahalle içinde yer almaktadır. Üç katlı ahşap ev, merkezi sofalı tipik bir Türk evi planına sahiptir. Ancak Sultan II. Mahmud devrinde güney tarafında ilave edilmiş gelin odası özgün planın değişmesine sebep olmuştur. Türk ev mimarisinin günümüze ulaşmış en eski tanıklarından olan Kavafyan Evi, uzun yıllar korunmuştur ancak son zamanlarda kullanım dışı kalmış olup günümüzde kaderine terk edilmiş durumdadır (Şekil 5).

\section{Reisülküttap Mustafa Efendi Yalısı (Yılanlı Yalı), 1763}

Tavukçu Reis olarak anılan, Reisülküttap (Dışişleri Bakanı) Mustafa Efendi'nin yalısı 1763 'te inşa edilmiştir (Kayra, 1993, s.49). Harem kısmı kırk odadan fazlaydı. İçinde güzel tavanlı salonları, geniş sofaları vardı. Yalının en güzel odalarından biri, geniş kapısının sağındaki büyük taş odaydı. Odanın tavanı kubbeli ve kâgirdi. Oldukça geniş, ahşap yapının içerisinde havuz da mevcuttu. Bahçesi, Robert Koleji'nin arkasından Rumelihisarı'ndaki Zağnos Paşa Kulesi'ne kadar uzanırdı. Sebze, meyve bahçeleri, üzüm bağları, su hazneleri, musluklar, setler halindeki bahçede yer alırdı. 1910 yılında yalı kötü bir şekilde restore edilmiş, özgün öğelerini yitirmiştir. Taş odadaki havuz yıktırılmış, selsebil sökülmüş, zemini ahşap kaplanmıştır. 1964'te yanmış, harem 
kısmı yok olmuştur (Şehsuvaroğlu, 1986, s.234), 1980'lerin sonunda yapı, büyük ölçüde yeniden inşa edilmiştir. Günümüze özgün haliyle ulaşamamış olup replikası mevcuttur (Şekil 5).

\section{Ali Paşa Sahilhanesi, 1781- Valide Hidiv Sahilhanesi, 1900}

Boğaziçi'nin en güzel ve büyük sahilhanelerinden biri olan bu yalının ilk sahibi, Dürrizâde Esseyit Mehmet Ataullah Efendi'dir. Sururi Efendi'nin dörtlüğünden, bu yalının 1781 yılında inşa edildiği anlaşılmaktadır (Şehsuvaroğlu, 1986, s.235). Dürrizâdelerden sonra, yalı Sadrazam Mehmet Emin Rauf Paşa, 1859 yılında Rauf Paşa'nın ölümünden sonra ise Ali Paşa tarafından satın alınmıştır. Ali Paşa'nın Hariciye Nazırlığı'nda pek çok önemli konferanslara, davetlere sahne olan yalı (Şehsuvaroğlu, 1986, s.235), Ali Paşa'nın ölümünden sonra Osmanlı Devleti'ne bağlı son Mısır Hıdivi Abbas Hilmi Paşa'nın annesi, İstanbul'da Validepaşa lakabıyla meşhur Mısırlı Prenses Emine Hanım’a geçmiştir (Koçu, 1961e, s.2334). Prenses, Hicri 1318 yılında (Miladi 1900/1901) ahşap yalıyı yıktırıp yerine kârgir bir yalı yaptırmıştır (Şehsuvaroğlu, 1986, s.237). Valide Hıdiv Sahilhanesi olarak da bilinen yalı, prensesin ölümünden sonra elçilik binası olarak kullanılmak üzere Mısır Devleti'ne hibe edilmiştir (Koçu, 1961e, s.2334). Günümüzde Misır Konsolosluğu olarak kullanılmaktadır (Şekil 5).

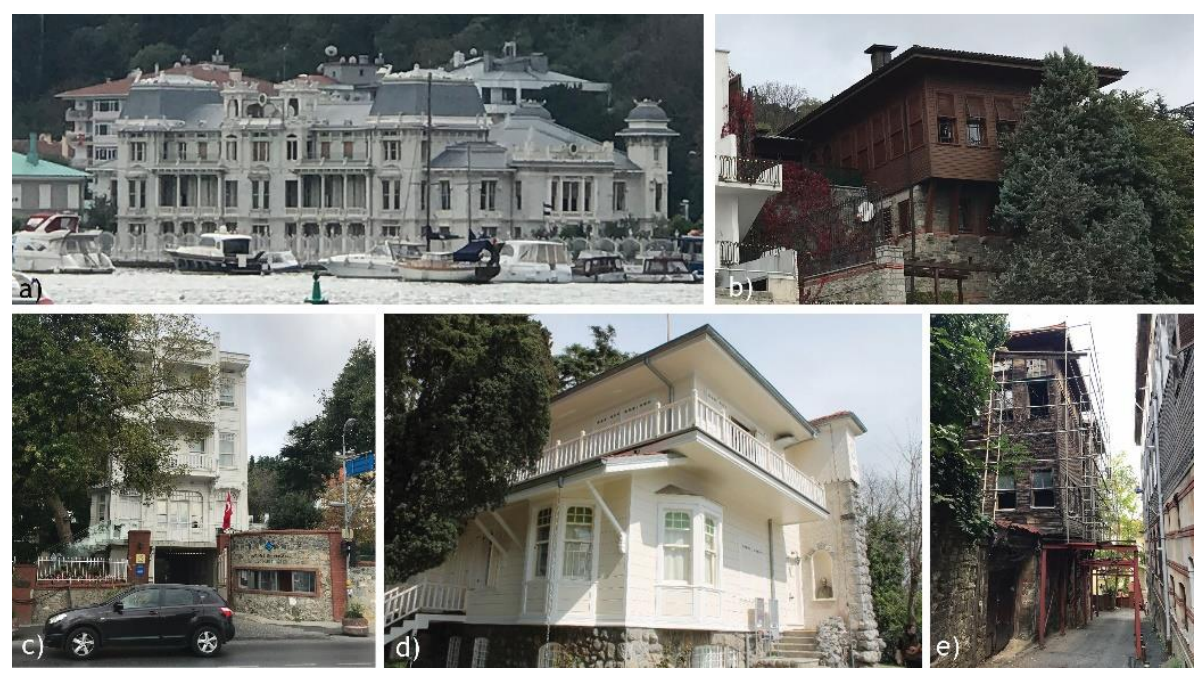

Şekil 5. Bebek'te günümüze ulaşmış tescilli yalılar/konaklar. a) Valide Hıdiv Sahilhanesi (Kaynak: yazarın fotoğraf arşivi) b) Yılanlı Yalı (Kaynak: yazarın fotoğraf arşivi) c) Eski Robert Koleji giriş binası (Kaynak: yazarın fotoğraf arşivi) d) Tevfik Fikret Evi (“Müzeler”, t.y.) e) Kavafyan Evi (Kaynak: yazarın fotoğraf arşivi) 


\section{Robert Koleji Giriş Binası}

Robert Koleji'nin inşası sırasında anıtsal giriş/koru kapısı yerine inşa edilen bu ahşap sahilhane (Erdenen, 1994, s.761), günümüzde Boğaziçi Üniversitesi'nin Bebek Kapısı Köşkü olarak bilinmektedir. 2016-2018 yılları arasında restore edilmiş, Rektörlük misafirhanesi işlevi verilmiştir ("Gürsoy”, t.y.) (Şekil 5).

\section{Tevfik Fikret Evi (Aşiyan Müzesi)}

Şair Tevfik Fikret in 1906-1915 yılları arasında yaşadığı ev olan Aşiyan, 1940 yılında eşi Nazime Hanım 'dan İstanbul Belediyesi tarafından satın alınıp, 1945 yılında Edebiyat-1 Cedide Müzesi olarak açlmıştır. Tevfik Fikret' in daha önceleri Eyüp mezarlığında bulunan naaşı, 1961 yılında doğal görünümü ile çok beğendiği bu bahçeye nakledilmiş ("Bebek-Rumelihisarı", 1942) ve bu tarihten sonra müze, Aşiyan Müzesi adını almıştır (Koçu, 1961a, s.1161) (Şekil 5).

\section{Yüzyıldan 20. Yüzyılın ilk çeyreğine Bebek ve Yapıları}

19. yüzyıl, Osmanlı Devleti'nde yenileşmenin en yoğun olduğu dönemdir. Tanzimat Fermanı, Islahat Fermanı ve I. Meşrutiyet'in ilanı ile ilk anayasanın (Kanun-i Esasi) yürürlüğe girmesiyle birlikte büyük reformlar hayata geçirilmiştir (Karabulut, 2016, s.50). Osmanlı modernleşmesinin dönüm noktasını oluşturan, 1839 Tanzimat Fermanı sonrası, devleti ve toplumu çağdaşlaştırmak için öngörülen düzenlemeler kentte bir Batılı başkent yaratma isteği olarak yansımıştır. Tüm yetersizliklere rağmen bu dönemde yoğun bir yapı faaliyetine girişilmiş, bu durum mimari yapıda ve kentsel mekânda önemli değişimlere neden olmuştur. Eski devlet yapısının modern dünyaya uyarlanabilmesi için gereksinim duyulan yönetim, eğitim, askeri ve kamu düzenine ait yeni yapı türleri, Batı mimarlığının tasarım kalıpları ve üsluplarıyla gelişmiştir. Bu dönemde modernleşme sürecinden etkilenen Sultan Abdülaziz (1830-1876), Boğaziçi kıyılarında yer alan eski ahşap sarayları yıktırarak kâgir saraylar inşa ettirmiştir (Yergün, 2002, s.18). Böylece geleneksel kent imgesi de değişmeye başlamıştır.

19. yüzyılda İstanbul'da dolayısıyla Bebek'te yapı çeşitliliği bir hayli artmış, bu durum 20. yüzyılın başında da devam etmiştir. Karakol gibi güvenlik birimleri, telefon, telgraf, postane gibi iletişim yapıları, tramvay istasyonları ve iskeleler gibi ulaşım yapıları, deniz hamamları, gazino gibi eğlence yapıları, bu dönemde görülen yapı tiplerindendir. Bunun yanında Bebek'te çeşmeler, sarnıçlar gibi su yapıları ile kahvehaneler de yer almıştır. 1856'da ilan 
edilen Islahat Fermanı'nda, gayrimüslimler pek çok hak elde etmiş, daha geniş yaşam alanına sahip olmalarıyla dini yapılar çeşitlenmiş, yabancı okullar çoğalmıştır. Müslüman okullarının da fazlalaşması eğitime, yetimhanelerin inşa edilmesi, sosyal kurumlara verilen önemin arttığının bir göstergesidir.

\section{Ulaşım Yapıları}

19. yüzyılın getirdiği yeniliklerden biri, ulaşım alanında olmuştur. Osmanlı Devleti ile Avrupa arasında gelişen ilişkilerle ulaşım konusunda yeni imkanlar yaratılmış, gemi, vapur, tren, tramvay gibi araçlar ulaşım ağının içerisine katılmış, bu doğrultuda istasyon yapıları, iskeleler inşa edilmiştir. Bunun yanında 19. yüzyıl ortasında Boğaziçi'nde ikamet edenlerin şehre geliş gidişlerini kolaylaştırmak amacıyla Osmanlı Devleti'nin ilk anonim şirketi olan Şirket-i Hayriye'nin de kurulmasıyla Boğaziçi'nde dolayısıyla Bebek'te nüfus artmıştır. Şirketin kurulmasını takiben Anadolu ve Rumeli yakalarına iskeleler inşa edilmiştir (Akyıldız, 2010, s.201). Bu dönemde Bebek, vadi içlerine doğru gelişmiştir (Salman, 2004, s.30).

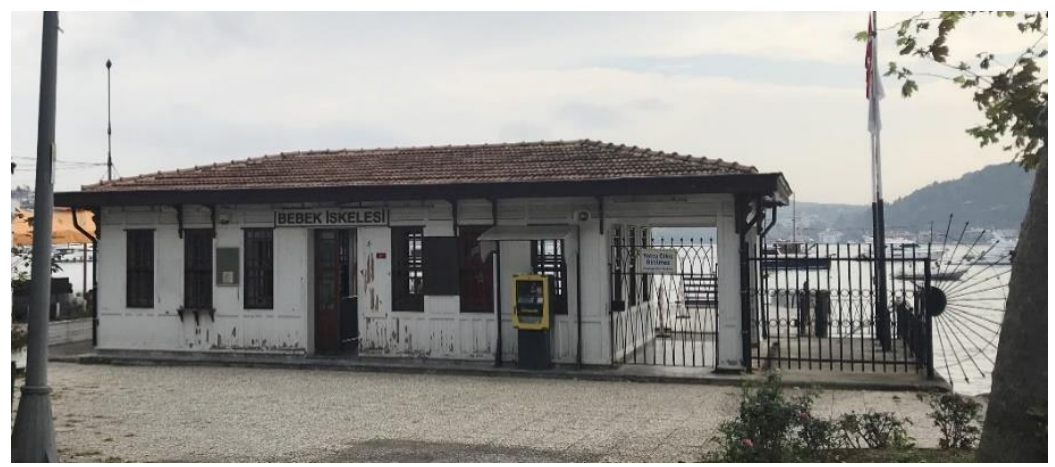

Şekil 6. Bebek İskelesi, 2019 (Kaynak: Yazarın fotoğraf arşivi)

\section{Bebek İskelesi, 1851}

Bebek İskelesi, ilk olarak 1851 yılında tek katlı ve ahşap olarak inşa edilmiştir. İskele ile ilgili, en eski arşiv belgesi 1886 tarihli olup iskele civarındaki çürüyen rıhtımın tamiri ile ilgilidir. 1894 yılında bir sıra kazık ilave edilerek iskele genişletilmiş, 1898 ve 1918 yıllarında tamir edilmiştir. 1899'da ise iskelenin merkez karyeye nakli veya yeni bir iskele inşası istenmiştir ("Şirket-i", 1317). 1920 yılında ahşap kazık çakılarak iskele bugünkü yerinde inşa edilmiş, 1986 yılında büyük bir onarım geçirmiştir. Eski Bebek İskelesi yetersiz kalınca hizmet dışı bırakılmış, betonarme kazık üzerine bir başka iskele yapılmıştır. Yeni iskele 2001 yılında Boğaz hattı gemilerinin hizmetine girmiştir 
("Envanter", t.y.a). Eski iskele ise günümüzde tescilli olup kafeterya olarak kullanılmaktadır (Şekil 6).

\section{Bebek Tramvay İstasyonu, 1926}

Bebek'teki tramvay ve hattı hakkında, Osmanlı Arşivi belgeleri içerisinde 1914-1925 yılları arasına tarihlenen 10 belge vardır. Bunların altısı 1914 tarihli olup Bebek Bahçesi arkasında tramvay şirketince yapılan hafriyatın iptali hakkındadır. Belgelere göre 1914'te Bebek'e tramvay getirilmesi için önce yollar genişletilmiş ("Ortaköy-Bebek", 1914) daha sonra tramvay ulaştırılmıştır. 1921'de tramvayın çift hatta geçilmesi gündeme gelmiştir ("Ortaköy-Bebek", 1921). Ortaköy-Bebek tramvay hattının yapımına başlanmasına ait belge 1925 tarihlidir ("Eminönü", 1925). Haritalarda tramvay istasyonu binası ise 1926 ve 1929 yillarında görülmektedir.

\section{Haberleşme Yapıları}

Osmanlı Devleti'nde haberleşme hizmetleri, menzilhaneler üzerinden yürütülmekteyken Tanzimat'ın ilanından sonra 1840'ta Posta Nezareti kurulmuş ve yeni Posta Nizamnamesi yürürlüğe girmiştir. Bu kurum, 1871'de Telgraf Müdürlüğü ile birleştirilerek Posta ve Telgraf Nezareti olmuştur. 1909 'da haberleşme hizmetlerine telefonun da eklenmesiyle 1911 yılında Posta Telgraf ve Telefon Nezareti unvanını almıştır (Yazıcı, 1985, s.1637).

\section{Posta Telgraf Telefon Binast}

Bebek'te 1869 'da bir telgraf merkezi açlmıştır ("Bebek ve", 1286). 19141929 yılları arasındaki haritalarda, Bebek'te telefon ve postane için iki ayrı binanın yer aldığı görülmektedir. 1914, 1918³ ve 1926 tarihli haritalarda Hamam ve Bakkal sokakları arasındaki Telefon binası, 1918, 1926, 1927 ve 1929 tarihli haritalarda ise Bebek Caddesi üzerinde Postane binası mevcuttur (Şekil 7). Bu yapılarla ilişkili olarak Devlet Arşivlerinde 1894-1907 yılları arasına tarihlenen yedi belge, çekilen telgraflar ile ilgilidir ("Bebek'den" 1313; “Hidivin", 1318; "Misır hidivi", 1324; "Misır hidivi", 1326; "Misır Hidivi", 1323; "Mısır Hidivinin", 1321; “Ticaret", 1312). Bu telgrafların büyük bir kısmı M1sır hıdivi ve validesi tarafından çekilmiştir. Bunların haricinde, çalışanların maaşları, zamları, telgraf ücretleri gibi konular ile ilgili arşiv belgeleri mevcuttur. Söz konusu yapılar günümüzde mevcut değildir.

\footnotetext{
${ }^{3}$ Necip haritası, Atatürk Kitaplığı'nda tarihsiz olarak belirtildiyse de İstanbul Büyükşehir Belediyesi Boğaziçi İmar Şube Müdürlüğü arşivinde 1918 tarihli olarak görüldüğü için bu tarih dikkate alınarak değerlendirme yapılmıştır.
} 

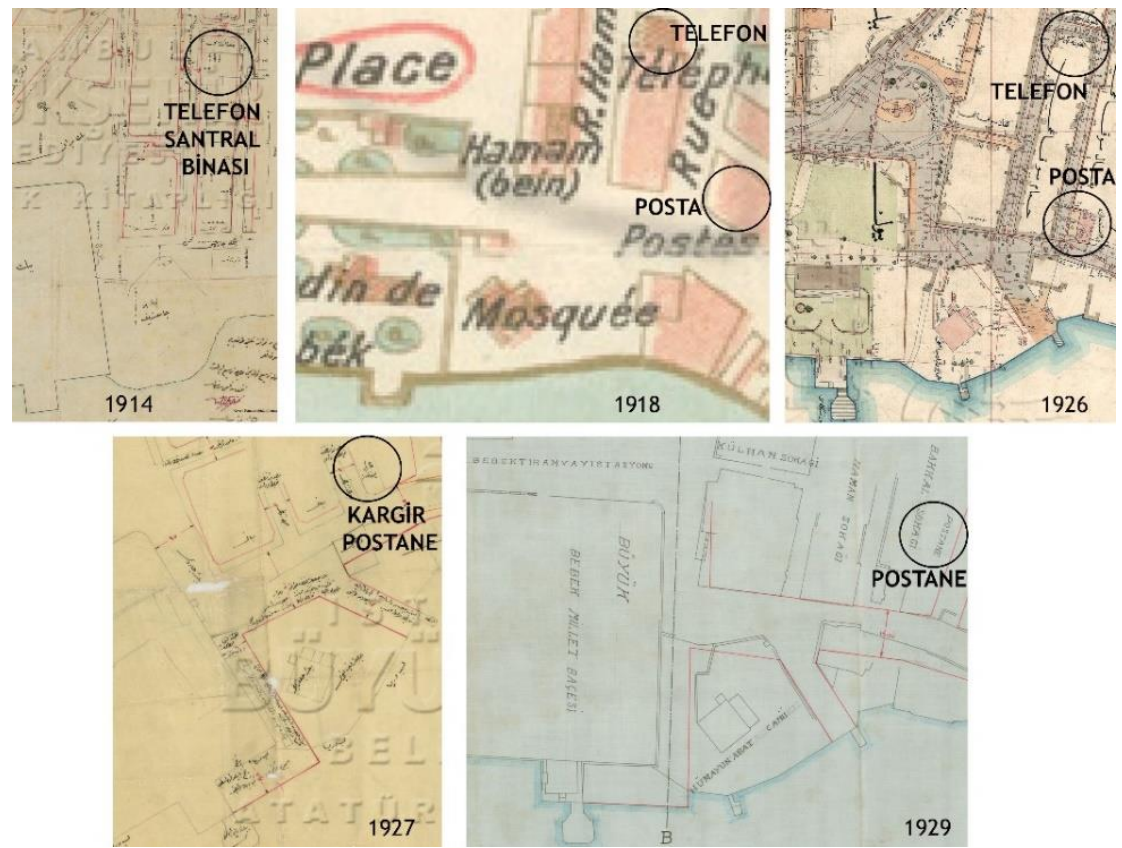

Şekil 7. 1914-1929 tarihleri arasındaki haritalarda Telefon ve Postane binaları (Soldan sağa doğru kaynaklar: "Beşiktaş-Bebek”, 1329; Nedjib (t.y.); “Beşiktaş-Bebek”, 1927; “Rumeli ciheti 87", 1926; "Beşiktaş-Bebek", 1929).

\section{Eğitim Yapıları}

Tanzimat'ın getirdiği yeniliklerden bir diğeri de eğitim alanında olmuştur. Yeniliklerin halka benimsetilmesi ve geleneğin kırılması amacıyla dönemin devlet adamları eğitime önem vermişlerdir. Bu dönemde ortaya çıkan yeni eğitim yapılarının yanı sıra geleneği temsil eden eski eğitim kurumları da varlıklarını sürdürmeye devam etmişlerdir (Poyraz ve Öztop, 2013, s.315). Bunun yanında, yabancı devletlere tanınan ticari kapitülasyonlar yanında dini serbesti, misyonerlerin imparatorluk topraklarına gelmesine ve zaman içinde okullar açmalarına yol açmıştır. Osmanlı Devleti'ndeki ilk yabancı okul, Beyoğlu'nda Fransızlar tarafından açılmıştır (Eren, 1944, s.38). Yabancı okullar 1700'lerden başlayarak çoğalmış, 1850'lerden sonra da yaygınlaşmıştır. 1869 tarihli Maarif-i Umumiye Nizamnamesi'nin 129. Maddesine göre yabancı okulların açılması padişah fermanına bağlıydı. Ancak uygulamada birçok okul resmi izin almadan açılmıştır (Erkan, 2001, s.238). Bu nizamnameyi takiben 1876 tarihli Kanun-i Esasi'nin 15. Maddesiyle azınlık ve yabancı okullara öğretim özgürlüğü ilkesi gelmiştir. Bu tarihten sonra yabancı okulların sayısı artmaya devam etmiştir (Erkan, 2001, s.238). 1915 yılında yayımlanan 
Özel Okullar Talimatnamesi ile yabancı okulların açılmasına sınırlar getirilmiş, bölgede okula gereksinim duyacak kadar yabancının bulunması ön koşul olarak koyulmuştur (Ergin, 1940, s.1234). Türkiye Cumhuriyeti'nin laik eğitim ve öğretim anlayışı doğrultusunda dini özellikli okulların düzenlemeleri değişmiş, 1926'da yayınlanan genelgeyle yabancı okulların sıkı bir denetim altına alınmasından sonra sayıları bir hayli düşmüştür (Sezer, 1999, s.82).

\section{Fransiz Okullarn}

Osmanlı Devleti'ndeki yabancı okullar zincirinin ilk halkası 1583'te kurulan Fransız Saint Benoit'dır (Eren, 1944, s.44). Misyonerler tarafından kilise ve manastırın yanında açılmış olup günümüzde çalışmalarını sürdürmektedir. Bebek'te dört adet Fransız okulunun yer aldığı tespit edilmiştir.

Saint Joseph Fransiz Okulu, 1853

1853'te Fréres des Écoles Chrétiennes rahipleri tarafından kurulmuştur. Yatılı ve yatısız bölümleri ile bir yetimhanesi vardır (Aksoy, 2015, s.45). Yetimhaneye ilişkin 1915 ve 1918 tarihli arşiv belgeleri mevcuttur ("Bebek ve Sen Jozef", 1336). İlkokul seviyesinde faaliyet gösteren okul, kurulmasının ardından uzun yıllar Bebek ve çevresindeki tek Katolik faaliyet merkezi olma özelliğini korumuştur. Birinci Dünya Savaşı sırasında kapanmış, 1918 Mondros Mütarekesi sonrası tekrar açılmıştır (Polvan, 1952, s.173). Günümüzde Bebek'te bu okul mevcut değildir.

\section{Saint Gabriel Fransiz Okulu, 1896}

1896' da Frères Maristes rahipleri tarafından kurulmuştur (Aksoy, 2015, s.45). Arşivde bu okul ile ilgili herhangi bir bilgiye rastlanamamıştır. Günümüzde yapı mevcut değildir.

\section{Lazarist Fransiz Okulu, 1896}

1896' da kurulmuş okul (Aksoy, 2015, s.46), 1910 yılında Fransuva'nın idaresindedir ("Bebek'te Fransuva'nun", 1328). 1910'da okulun tamiri ve inşaat vergilerinden muafiyet talebi gündeme gelmiş, 1911'de onaylanmıştır ("Bebek'teki Fransız", 1329). Okul, Yoğurthane Sokağı'nda yer almaktadır ("Bebek'te Yoğurthane", 1329). 1912 ve 1913 yıllarına ait belgelerde, Lazarist Mektebi'nin Lazarist rahipleri adına kayıtlarının düzenlenmesi ve vergiye bağlanması gerektiği belirtilmiştir ("Bebek'deki Fransız", 1331; "Fransa müessesatından", 1331;). Okul kapanmış olup günümüzde binası, özel Uğur Okulları tarafından kullanılmaktadır (Şekil 8a). 


\section{Soeurs de La Charite Fransiz Okulu, 1881}

Soeurs de La Charite (Şefkat Rahibeleri) sivil toplum kuruluşu tarafından Bebek'te 1881'de kurulmuştur. 1906 ve 1913 tarihli belgelere göre, Soeurs de La Charite rahibelerine aittir ("Bebek'de bulunan", 1331; "Bebek'de Şarite", 1906 ; "Bebek'deki Fransız", 1331). 1912 ve 1913 yıllarında, okulun kayıtlar1nın düzenlenmesinin ve vergiye bağlanmasının rahibeler adına yapılması gerektiği belirtilmiştir ("Fransız müessesatından", 1330). 1914 tarihli bir belgeye göre bu okulun bir de yetimhanesi vardır ("İstanbul Bebek'deki", 1332). Günümüzde okul binası, konut olarak kullanılmaktadır ("Beşiktaş İlçesi", 2014) (Şekil 8b).

1914 tarihli Osmanlı Arşivi belgesine göre, Bebek'te boşaltılan Fransız okullarının binaları, Darüleytam'a tahsis edilmiştir.
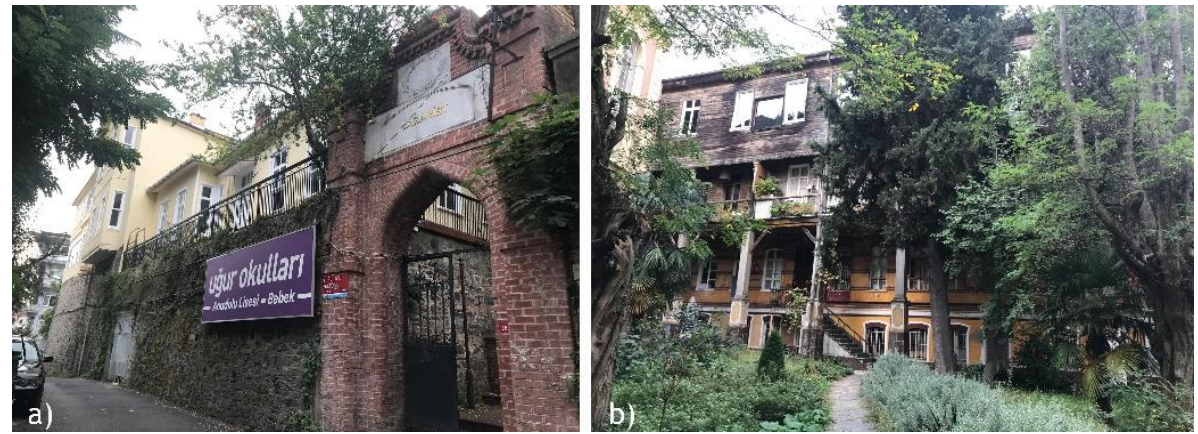

Şekil 8. Günümüzde mevcut olan; a) Lazaristlere ait Fransiz okulu, 2019 b) Soeurs de La Charite Fransız Okulu, 2019 (Kaynak: yazarın fotoğraf arşivi)

\section{Amerikan Okullarn}

\section{Robert Koleji}

İstanbul'un en önemli Amerikan okullarından Robert Koleji, 1863'ün Eylül ayında Bebek'te, Kırım Savaşı sırasında Türklere yardım etmek için gelen Amerikalı misyonerlerin bulunduğu küçük bir evde eğitime başlamıştır (Ergin, 1940, s.783). Bu misyonerlerden biri olan eğitimci Dr. Cyrus Hamlin'in girişimiyle ve Amerikalı tüccar Christopher Rhinelander Robert'ın finansal desteğiyle kolej açılmıştır. 1878'e kadar kolejin bütün masrafları Mr. Robert tarafından karşılanmış olup vefatından sonra vasiyeti üzerine kalan parayla Rumelihisarı'nda muazzam binalar inşa edilmiş ve o zamana kadar Amerikan Koleji denilen okul Robert Koleji adını almıştır (Eren, 1944, s.52). Daha sonra Ahmet Vefik Paşa'dan satın alınan Kayalar Mevkiindeki arazide kolejin binaları inşa edilmiş, zaman içerisinde bu yapılar çoğalmıştır. 1971'de bu yapı kompleksi devlete devredilmiş, Robert Koleji Arnavutköy'e taşınmıştır. 
Eski binaları ise o dönemde kurulmakta olan Boğaziçi Üniversitesi'nin kullanımına tahsis edilmiş olup bu kullanım günümüzde de devam etmektedir. Devlet Arşivlerinde Robert Koleji ile ilgili, 1878-1915 yılları arasına tarihlenen belgeler, müdür ve öğretmenlerin Ermenilerin hicretlerine yardım etmesi ("Ermeni meseleleri", 1313), diploma töreninde bir öğrencinin Rumca konuşmasında söylenenlerin münasebetsiz olduğu ("Bebek'de bulunan", 1324), müdüre devredilen arsa, savaş sebebiyle sinava gelemeyen Bulgar öğrencinin sinavlarının tekrarlanacağı gibi belgelerdir.

\section{Rum Okullarn}

Bebek Köy içi Rum Okulu, 1853

1853 yılında inşa edilen okul ("Bebek'de Rum", 1269), 1915'te Bebek Karma Rum Mektebi olarak anılmaktadır ve yabancı dil olarak Fransızca öğretmektedir (Kalaycı, 2008, s.680). 1920'de okul, Köy içi sokağında yer almaktadır ("Boğaziçi Bebek'te", 1338). 1926 yılında, eğitim öğretime Rum Ortodoks Cemaatine ait, iki kat, dört odalı ahşap bir binada devam ediyordu ve eğitim öğretim için gerekli fiziki ve teknik altyapıya sahip değildi (Yücel, 2016, s.199). 1950 yılında kapalı olan okul, Hristos Georgiadis tarafından iki sınıflı olarak yeniden açılmış, daha sonra 3., 4. ve 5. sınıflar da okula eklenmiştir. Bundan dolayı devletin kayıtlarında kuruluş tarihi 1950 olarak yazmaktadır ("Özel okullar", 1964, s.221). 1964 yılında dört öğretmen ve 35 öğrencisi olan okul ("Özel okullar", 1964, s.223), kapanmasına yakın, Ayios Haralambos Rum Ortodoks Kilisesi'nin de bulunduğu İnşirah Sokağı'nda yer alıyordu (Kalaycı, 2008, s.680). Okul günümüze ulaşamamıştır.

\section{Alman Okullarn}

Almanlar, okul konusunda Fransa ve Amerikan kuruluşlarına oranla fazla gelişme gösterememişlerdir. Bunun bir nedeni siyasi birlikten yoksun olmaları diğeri de Osmanlı topraklarında pek Alman vatandaşı olmamasıdır. 1870'ten sonra siyasal birlikleri kurunca başkentte sayıca artmaya ve okul açma girişimlerine başlamışlardır (Eren, 1944, s.55). Bebek'te varlığı bilinen tek Alman okulunun, bu girişimlerin sonucunda açıldığı düşünülmektedir.

\section{Bebek Alman Okulu (Kız Mektebi)}

Bebek'teki Alman Mektebi ile ilgili, arşivde sekiz belge vardır. Bunların beşi, Erzurum ve Elazığ'dan bu okula çocukların getirilmesi hakkındadır. Bu belgeler okulun yatılı olduğunu ve pek fazla öğrencisinin bulunmadığını düşündürmektedir. 1895'te Erzurum'dan Bebek'teki Alman Mektebi'ne gönde- 
rilecek çocuklar, Alman doktor Harli'nin gözetiminde İstanbul'a getirilmişlerdir (“Bebek'teki Alman”, 1313). 1897 yılında Elâzığ'dan 45 yetim çocuk, bu okula kaydolmak üzere yola çıkmıştır (“Mamuretülaziz'den”, 1315) Aynı yıl, Harput'tan da 25 Ermeni çocuk refakatçileri ile buraya gelmiş olup ("Dersaadet" 1315) daha fazla çocuğun getirileceği belirtilmiştir ("Bebek'teki Alman", 1315) 1898'de müdürünün Pastör Brokes olduğu ve Harput'ta Bebek Alman Okulu'nun bir şubesini açmak istediği bilinmektedir (Zamacı, 2009, s.75). 1906 öncesinde okulda birtakım değişiklikler yapılmış olmalı ki, 1906 tarihli iki belgede Alman Sefareti himayesindeki kız mektebinin eski haline döndürülmesi ve talibine satılmasından söz edilmektedir ("Bebek'de Alman", 1324; "Bebek'te Almanya", 1324;). Okulun satılıp satılmadığı ve sonrası bilinmemektedir.

\section{Müslüman Okullan}

Feyzani Mektebi

Bebek sahilindeki Sait Paşa Yalısı'nın bir dönem Feyzani Mektebi olarak kullanıldığı bilinmektedir (Eldem, 1993, s.128). Ancak okul hakkında bir bilgiye ulaşlamamıştır.

\section{Hayme Ana Kız Numune Mektebi}

1916 tarihli arşiv belgelerinde, Bebek'te Hayme Ana Kız Numune Mektebi'nden söz edilmektedir ("Bebek Hayme", 1334). Hayme Ana'nın Osman Gazi'nin babaannesi olduğu göz önüne alınarak bir Müslüman okulu olduğu düşünülmektedir. Ancak okul hakkında başka bir bilgiye ulaşılamamıştır.

\section{Darüleytam (Yetimhaneler)}

1877-78 Rus Savaşı'nın kaybedilmesiyle birçok insan hayatını kaybetmiş, pek çok çocuk yetim kalmıştır. II. Meşrutiyet döneminde (1908-1920) açılan darüleytamlar (yetimhaneler) bu amaçla kurulmuşlardır. Bu dönemde içinde bulunulan koşullardan dolayı devletin açtı̆̆ yetimhaneler yetersiz kalmış, bu süreçte yabancı devletler de yetimhane açmaya başlamış ve kimsesiz çocukları kendi amaç ve fikirleri doğrultusunda eğitmişlerdir (Tekin, 2018, s.187). Osmanlı Arşivinde Bebek yetimhanesi ve Hoca İsmail Mahir Efendi yetimhanesi olarak iki farklı isimde yetimhaneye ait belgeler mevcuttur.

\section{Bebek Yetimhanesi}

Osmanlı Arşivinde Bebek yetimhanesi ile ilgili 1916-1922 yılları arasına tarihlenen belgeler, inşaat defteri ("Darüleytam Bebek", 1318), öğretmenler ("Taltifat", 1340), maaşlar ("Alınan karardan", 1340) ve malzemeler ("Fransa Devleti", 1243) hakkındadır. Bebek Yetimhanesi'nin Hoca İsmail Mahir 
Efendi Yetimhanesi ile aynı kuruluş olması, Bebek'te yer aldığı için kısaca bu isimle anılıyor olması da ihtimal dahilindedir.

\section{Hoca İsmail Mahir Efendi Yetimhanesi}

1917 ve 1918 tarihli arşiv belgelerine göre Bebek'te Hoca İsmail Mahir Efendi yetimhanesi yer almaktadır. Arşiv belgeleri, burada yapılan inşaat ve çıkan bulaşııı hastalık hakkındadır ("Fransa Devleti", 1243)

\section{Askeri Yapılar}

Osmanlı Devleti'nin güvenlik amiri olan Bostancıbaşı'nın emrindeki Bostancılar Ocağı teşkilatının geçmişi 14. yüzyıla dayanır. Bostancıbaşı defterlerinde Bebek Kasrı'nın yanında bir Bostanc Ocağı'nın bulunduğu bilinmektedir (Germiyanoğlu, 1961, s.2338). Bostancı örgütü 1827'de kaldırılmış yerine karakol binaları yapılmıştır (Çiftçi, 2001, s.432). Kent içi güvenlik hizmetini sağlayan karakollar, Tanzimat devrinin getirdiği yapı tiplerindendir. 1845 y1lında kurulan polis teşkilatı bünyesinde yerleşimin yoğun olduğu yerlerde ve bazı resmî yapıların yakınında polis karakolları, 1870 yılından sonra gelişen jandarma teşkilatı bünyesinde de kent merkezi dışındaki alanlarda jandarma karakolları inşa edilmiştir (Çiftçi, 2001, s.230). Ebniye Nizamnamelerinde de yeni kurulan semtlerde karakol için arazi ayrılması notu düşülmüştür (Çiftçi, 2001, s.231).

\section{Büyük (1843) ve Kïçük Bebek Karakollarn (1904 öncesi)}

Eski haritalarda, Bebek'te iki karakolun var olduğu tespit edilmiştir (Şekil 9-12). Biri Büyük Bebek'te, Bebek Bahçesi'nin güneyindeki jandarma karakoludur (Bebek Karakolu), diğeri ise Küçük Bebek Meydanı'ndaki polis karakoludur. Ancak Devlet Arşivlerinde belgeler genellikle Bebek'teki karakol olarak tanımlandığı için bazı belgelerin hangi karakola ait olduğu net olarak anlaşılamamaktadır.

"Bebek Bahçesi'ndeki bir Karakolun 1259 Tarihli Kitabesi” başlıklı belgeden ("Bebek Bahçesi'ndeki”, t.y.), 1843'te Büyük Bebek Karakolu'nun inşa edildiği anlaşılmaktadır ${ }^{4}$. Bunu destekler şekilde 1843 tarihli bir Osmanlı Arşivi belgesinde de Bebek'te karakol binasının inşa edileceği belirtilmiştir ("Bebek Arnavutköyü", 1259). Bebek'teki karakollara ait arşiv belgeleri, 1840, 1843, 1851 (tamir), 1871 (inşa masrafının ödenmesi), 1889 yıllarına aittir. 1889 'da Bebek Karakolu'nun yeniden inşa edildiğine dair bir belge olmasına

\footnotetext{
${ }^{4}$ IRCICA Kütüphanesi'nde bulunan bu belge tasnif aşamasında olduğu için görülememiş, sadece başlığı üzerinden yorumlanabilmiştir.
} 
rağmen ("Bebek Karakolhanesi'nin", 1306) 1894'te yıkılmak üzere olduğu anlaşılmaktadır ("Yıkılmak üzre", 1312). Tarihsiz bir arşiv belgesinde, Büyük Bebek Karakolu'nun arkasında hamamı, tuvaletleri, kömürlüğü, kileri, bahçe içinde türbesi ve su kuyusu ile adeta bir kompleks olduğu görülmektedir (Şekil 10). Bu belgede, 1859-1900 yılları arasında mevcut olan Ali Paşa Sahilhanesi'nin görülmesi belgenin bu yıllar arasına tarihlendiğini göstermektedir. Abdullah Kardeşler tarafından çekilmiş ve Bebek'teki Aziziye Karakolhanesi olarak belirtilmiş fotoğraflardaki yapı (Şekil 11), plan olarak Büyük Bebek'teki Karakol ile benzerlik göstermektedir. 1926 tarihli haritada, yerinde Bebek İlk Mektebi görülmektedir (Şekil 9d) ("Rumeli ciheti A", 1926). Küçük Bebek Karakolu ise 1904 ile 1940 yılları arasındaki haritalarda mevcuttur (Şekil 12). Bu Polis Karakolu'nun arsası 1942' de bedelsiz olarak Belediye'ye devredilmiş olduğundan ("Bebek-Rumelihisarı", 1942) 1942'den önce yıkılmış olduğu düşünülmektedir.
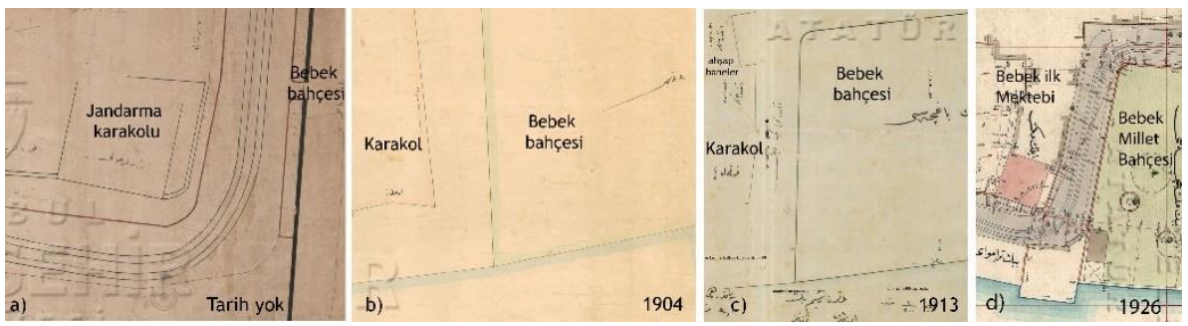

Şekil 9. Eski haritalarda Bebek Karakolu (Kaynaklar: a) "Beşiktaş-Bebek”, t.y. b)

"Beşiktaş-Bebek vapur", 1320 c) “Beşiktaş-Bebek”, 1329) (görsel üzerindeki yazılar yazar tarafından işlenmiştir).

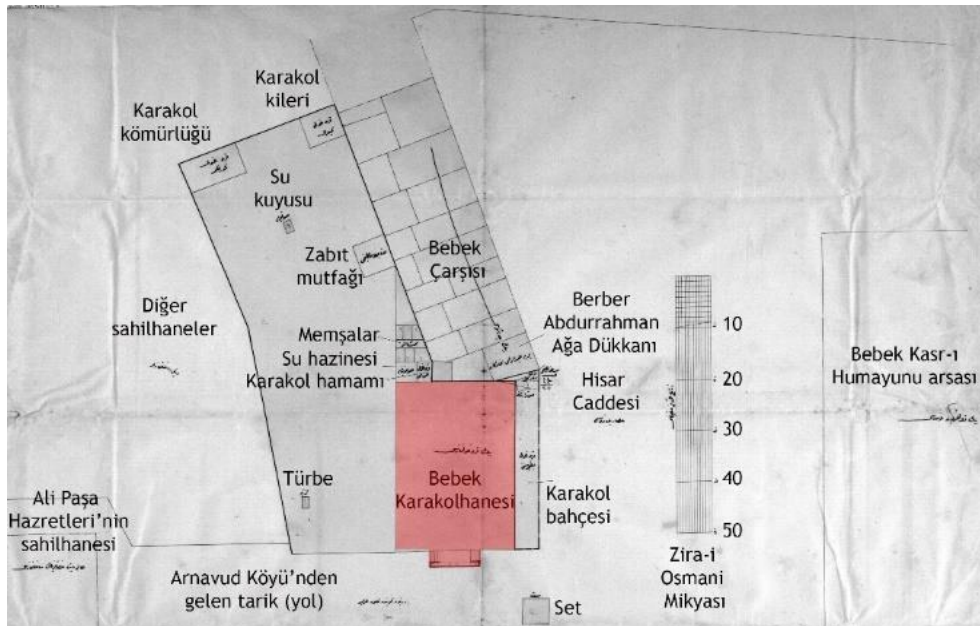

Şekil 10. Bebek Karakolu ve çevresine ait plan (Kaynak: “Bebek Karakolhanesi'ne”, 1282). 

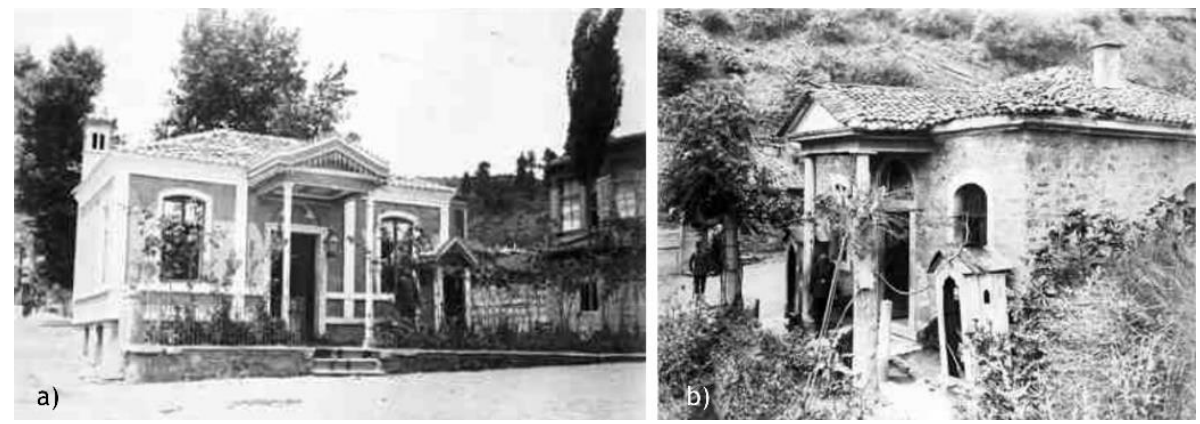

Şekil 11. II. Abdülhamit Arşivi'nden Aziziye (Büyük Bebek) Karakolu (Kaynaklar: a) Abdullah Frères, t.y.a b) (Abdullah Frères, t.y.b)
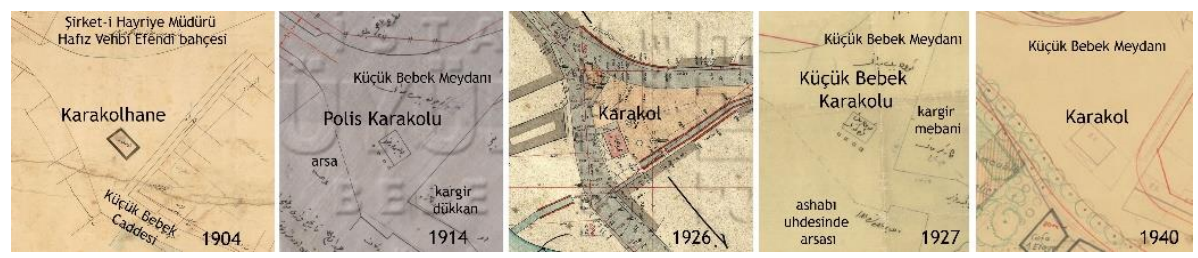

Şekil 12. Eski haritalarda Küçük Bebek Karakolu, (Kaynaklar: soldan sağa; "Beşiktaş-Bebek vapur", 1320; "Beşiktaş-Küçük”, 1330; “Rumeli ciheti 87”, 1926; “Beşiktaş-Bebek”, 1927; Prost (t.y.)) (görsel üzerindeki yazılar yazar tarafından işlenmiştir).

\section{Su yapıları}

Bir su şehri olan İstanbul'un Boğaz köyü Bebek'te su ile ilişkili pek çok yapı yer almıştır. Çeşme, hamam, sarnıç, su terazisi, deniz hamamlar, bunlardandir.

\section{Su Terazisi ve Su Sarnicı}

Su terazileri, çeşme, sebil, cami ve hamamlara gerekli suyu sağlayan, suyollarında basıncı ayarlayan ve suları ölçerek dağıtan mimari öğelerdir (Cantay, 1999, s.73). Günümüzde İnşirah Sokağı üzerinde bir su terazisi ve Kortel Korusu içerisinde bir sarnıç kalıntısı vardır ("Beşiktaş ilçesi”, 2014) (Şekil 13). 


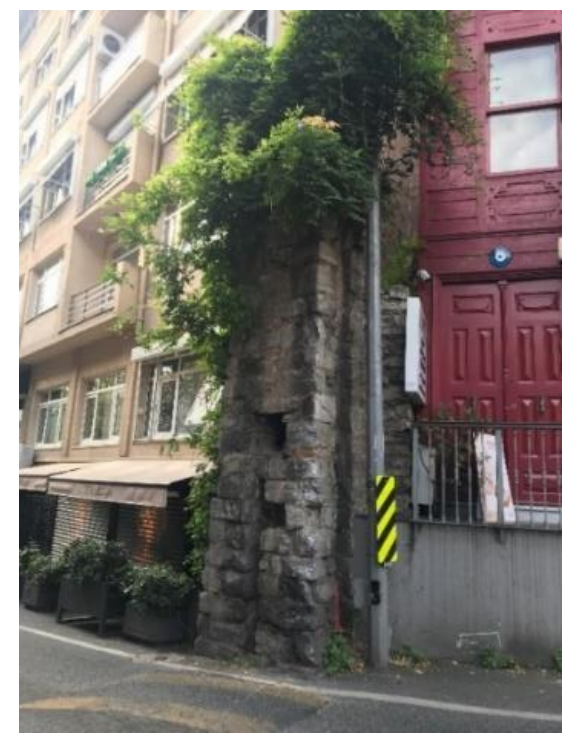

Şekil 13. Su terazisi kalıntısı (Kaynak: yazarın fotoğraf arşivi)

\section{Deniz Hamamlarn, 19. yüzyıl}

Deniz hamamları, İstanbul'da 19. yüzyılda görülmeye başlanan, denize girmek amaçlı yapılardır. Bebek'te iki adet umumi deniz hamamı olup bunlar Bebek Koyu'nun derin, akıntısız, temiz denizinde kurulmuştur (Koçu, 1961c, s.2336). 1845 tarihli arşiv belgesi bu tarihte yapıların kullanılıyor olduğunu göstermektedir ("Bebek kasr1", 1261).

\section{İbrahim Kethüda Çeşmesi, 1804}

Bebek Karakolu'nun önündeyken caddenin genişletilmesi sırasında Sarıyer Hac Osman Bayırı'na nakledilmiştir. Çeşme, iki ince sütun arasına yerleştirilmiş düz bir mermer ayna taşı ile üstündeki kitabeden oluşmaktadır (Şekil 14). Kitabesi şöyledir: “Kethüda Bey Kâbe-i ... İbrahim-veş, Mâ-1 zemzem ile kandırdı ıtâş-1 âlemi, Merdüm-i çeşm-i cihan kıldı Bebek etrafını, Sû-be-sû hayr ile tenvir itdi feyzi makdemi, lülesinden âb-1 cevher akdı târihin didim, Ayn-1 cûd-i Kethüda Bey kıldı icrâ zemzemi (1219)"5 (Egemen, 1993, s.400).

\section{Beyhan Sultan Çeşmesi, 1804}

Beyhan Sultan Sarayı'nın tamamlandığı yıl olan 1804'te inşa edilen çeşmenin üzerinde Enderunlu Vâsıf (ölüm 1240/1824) tarafından yazılmış üç kıtalık

\footnotetext{
${ }^{5}$ Kitabede, Kethüda İbrahim Bey'in susamış halkı zemzem suyu ile doyurduğu, Bebek'in etrafını dünyanın gözü haline getirdiği, her tarafı bolluk bereketi ile aydınlattığı, bu zemzemi eli açık Kethüda Bey'in yaptığı anlatılmaktadır.
} 
bir kitabe bulunmaktaydı (Tanışık, 1943, s.129). Kitabe şöyleydi: Vasıf'a şayeste tahrir eylesem tarih-i tam, Yaptı Beyhan âlâ tarh-ı dilcu çeşmesar 1219 (Miladi 1804). Osmanlı devri Türk sanatının en güzel eserlerinden olan Beyhan Sultan Çeşmesi, cadde genişletme çalışmaları sırasında uygun bir yerde tekrar yapılmak üzere tamamen sökülmüş fakat yeniden yapılmamıştır. 1985 yılında projeleri hazırlanmış ve tekrar inşa edileceği yerin tespiti yapılıp gerekli izinler alınmışsa da inşaata başlanamamıştır (Eyice, 1992, s.65). Çeşme daha sonra sahil yolunda yeniden inşa edilmiştir.

\section{Lütfi Bey Çeşmesi, 1905}

Lütfi Bey Çeşmesi, Sultan II. Abdülhamid tarafından, saray görevlilerinden Lütfi Bey için 1905 yılında yaptırılmıştır. Bebek Karakolu'nun arkasında inşa edilmiş, yol genişletmeleri sırasında bugünkü Küçük Bebek Caddesi üzerindeki yerine taşınmıştır. 2005 yılında Beşiktaş Belediyesi tarafından restore edilmiş olup günümüzde bakımlı durumdadır (Egemen, 1993, s.488) (Şekil 14).

\section{Yoğurtçu Zülfü Sokağı Üzerindeki Çeşme}

Yoğurtçu Zülfü Sokağı'nda, harap durumda, günümüzde kullanılmayan, tescilli bir çeşme mevcuttur (Şekil 14).

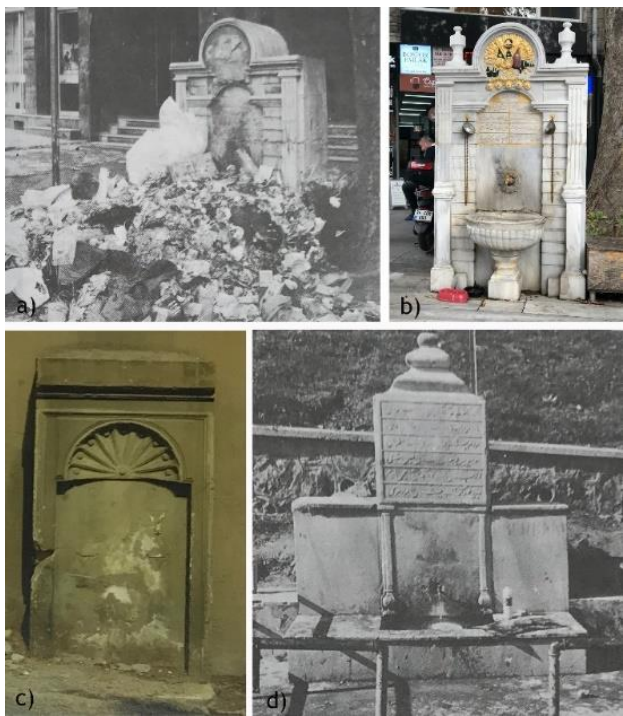

Şekil 14. Bebek'teki çeşmeler a) Lütfi Bey Çeşmesi, 1976 (Kaynak: Egemen, 1993) b) Lütfi Bey Çeşmesi, 2019 (Kaynak: yazarın fotoğraf arşivi) c) Yoğurtçu Zülfü Sokağı üzerindeki çeşme, 2014 (Kaynak: “Beşiktaş ilçesi”, 2014) d) İbrahim Kethüda Çeşmesi, 1972 (Kaynak: Egemen, 1993) 


\section{Dini Yapılar}

\section{Aya Haralambos (Horalatyus) Rum Ortodoks Kilisesi, 1830}

Bu kilise ile ilgili en eski veri, 1796 yılının Nisan ayına aittir (Millas, 1996, s.466). Kitabesindeki bilgiye göre, Avarlara ait bir tapınağın kalıntıları üzerine inşa edilmiştir (Karaca, 2008, s.419). Kitabesi şöyledir:

"Putlara kurban vermek istemeyen Kharalampos, kendini kurban edilecek koyun gibi Tanrı'ya sundu. İsa'yı seven seçkinler, onun tapınağını Boğaziçi'ndeki Bebek'te eskiden Avarlara ait olan tapınağın (metohi) yerinde inşa ettiler. Ey parlak isimli kutlu önder, Büyük Ayı'nın damlaları akşam işaretini verirken, günahların karanlığında boğulanları bağışlamasını dile kurtarıc1dan (İ. Kuçuradi)" (Karaca, 2008, s.420).

Kilisede bulunduğu belirtilen Hz. Meryem ikonası üzerindeki 1804 tarihli yazıtta, Bebek köyünde bulunan saygıdeğer sarrafların bağışlarıyla süslendiği, 1830 yılında ise yeniden inşa edildiği belirtilmiştir (Millas, 1996, s.467). Yapının üzerinde 1830 tarihli tabelası vardır. 1889 tarihli belgeye göre harap olan çan kulesinin tamirine izin verilmiştir ("Bebek karyesinde", 1307).

Kâdirî Tekkesi (Kadiriye Dergâhı), 19. yüzyıl

Kadiriye Tarikatı Dergâhı'nın şeyhi Abdülkadir Efendi hakkındaki bir arşiv belgesinden 1865 yılında yapının ayakta olduğu anlaşılmaktadır ("Bebek'de Tarikat-1", 1282). 1918 tarihli Necip Haritaları'nda Kadiri Dergâh,, Haşim Paşa Yalısı'nın arkasında görülmektedir. Daha yakın tarihli haritalarda ise bu dergâha rastlanamamaktadır. Bunun sebebi, Tevhid-i Tedrisat Kanunu'nu takiben 1925 'te Tekke, Zaviye ve Türbelerin Kapatılması Kanunu kapsamında kapanmış olmasıdır.

\section{Bebek Sinagogu, 19. yüzyıl}

1848' de vefat eden Haham Eliezer de Toledo'nun, Minşat Rebi Eliezer Toldeo Oreh Hayim ha yar Siman adlı kitabında, 1800'lerde Bebek'te mevcut bir sinagogdan bahsedilmektedir (Güleryüz, 2008, s.376). Ancak devlet arşivlerinde veya başka bir kaynakta bu sinagog hakkında herhangi bir bilgiye rastlanmamıştır.

\section{İngiliz Kilisesi, 1908}

Başbakanlık Osmanlı Arşivi'nde, Bebek'te İngilizler için bir kilise inşa edilmesi hakkında üçü 1908 yılına ait biri tarihsiz, dört kayıt tespit edilmiştir. Belgeler, kilisenin bir hane üzerine inşa edileceği ("Bebek'de İngilizlere", 
1326), Bebek'te Kilise Sokaği'ndaki ev ve arsa üzerine inşası hakkındaki ruhsat talebinin kabul edildiği ("Bebek ve", 1326) ve kilise inşası için arsalı hanenin satın alınması hakkındadır. 1908 civarındaki haritalara bakıldığında herhangi bir İngiliz Kilisesi görülememektedir. 1911 tarihli haritada Kilise Sokağ üzerinde Aya Haralambos Kilisesi belirtilmiş olup İngiliz Kilisesi ile ilgili bir bilgi mevcut değildir. Günümüzde de Bebek'te İngiliz Kilisesi yoktur.

\section{Lazarist Fransız Sacre Coeur Katolik Kilisesi, 1910}

Lazaristlere ait Sacre Coeur (Kutsal Kalp) Katolik Kilisesi, 1896 tarihli Lazarist Okulu ile aynı avluyu kullanmaktadır. Bir haber sitesinde kilisenin 1910'da inşa edildiği yazmaktadır ("Bebek'teki”, 2018). 16 Mart 1910 tarihli kartpostalda da yeni kilise olarak ifade edilmiştir ("Sacre Coeur", 2020). 2008'de 49 yıllığına İstanbul Süryani Katolik Kilisesi Vakfı'na tahsis edilmiştir. Kilise günümüzde mevcuttur ancak çan kulesi yıkılmıştır (Şekil 15).

\section{Fransız Soeurs de La Charite Manastorları, 20. yüzyıl}

1912 tarihli Osmanlı Arşivi belgesine göre ("Fransız müessesatından", 1330) Soeurs de La Charite rahibeleri, 1913 tarihli belgeye göre de ("Fransa müessesatından", 1331) ayn kurumun rahipleri için bir manastırın varlığından söz edilmektedir. Rahibelerin manastırına ait 1906 tarihli ("Bebek'de Şarite", 1906), bir de dikişhanesi olduğuna ilişkin 1914 tarihli ("Bebek'de Kovan", 1330) belgeler mevcuttur.

\section{Fransız Kilisesi, 19. yüzyıl}

1886 tarihli bir Osmanlı Arşivi belgesinde, Bebek'te bir Fransız Kilisesi olduğu anlaşılmaktadır ("Beykoz'da", 1866). Söz konusu belgede söz edilen kilisenin ismi veya konumu belirtilmemiştir. Ancak Lazarist Sacre Coeur Katolik Kilisesi 1910 yılında inşa edildiğinden, 1886 yılında Bebek'te bu kiliseden başka bir kilisenin daha olduğu düşünülmektedir.
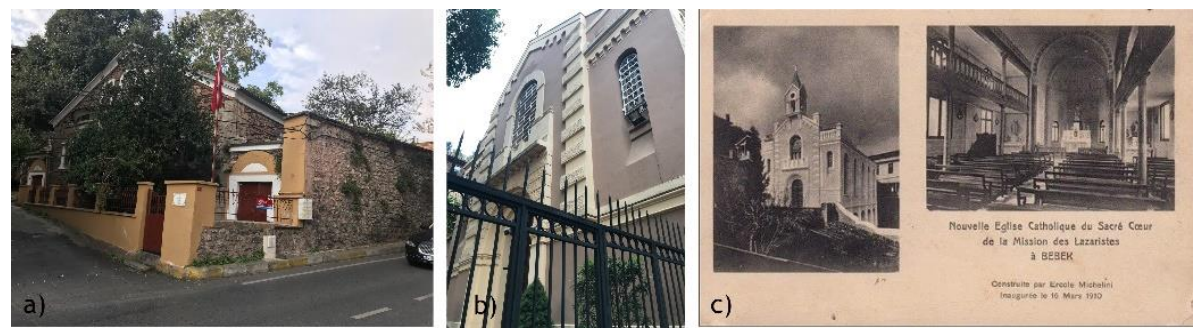

Şekil 15. a) Günümüzde Aya Haralambos Rum-Ortodoks Kilisesi (Kaynak: yazarın fotoğraf arşivi) b) Lazarist Sacre Coeur Kilisesi (Kaynak: yazarın fotoğraf arşivi) c) 1910 tarihli kartpostalda Lazarist Sacre Coeur Kilisesi ("Sacre Coeur", 2020). 


\section{Eğlence Yapıları}

\section{Şaraphane/Meyhane}

İçerisinde Bebek'in de olduğu çeşitli yerlerde bulunan şaraphane/meyhanelerden alınan vergiler hakkındaki tarihi belirtilmemiş iki arşiv belgesi, Bebek'te yer almış meyhanelerin varlığın kanıtlamaktadır ("Galata, Beyoğlu", t.y.).

\section{Gazino, 1908}

Bebek Parkı'nın içerisine 1908' de II. Meşrutiyetin ilanını takiben, halka hitap eden bir gazino inşa edilmiştir. Ekonomik geliri çok yüksek olmayan, orta direk olarak tabir edilen kesim dâhil her sınıf halkın nadir eğlence yerlerinden olan gazino, Başbakan Adnan Menderes döneminde, yakınındaki cami gerekçe gösterilerek önce kapatılmış, daha sonra 1957-1958 arasında imar düzenlemeleri sırasında yol genişletilirken yıkılmıştır (Koçu, 1961b, s.2331). Bebek Bahçesi'nde o dönemde açık hava konserlerinin verildiği bilinmektedir. 15 Eylül 1908'de Sabahaddin Bey'in başkanlığında bir konser verilmiş, konserde Ertuğrul Korveti mızıkası (bandosu) yer almıştır ("Sabahaddin", 1326).

\section{Yüzyılın İlk Çeyreğinden Günümüze Boğaziçi ve Bebek ile Yapılanı}

I. Dünya Savaşı'nı izleyen yıllarda Boğaziçi genelinde kentler boşalmış, bölge terk edilmiştir. Bebek'te de Saint Joseph Fransız Okulu bu dönemde geçici olarak kapanmış (Polvan, 1952, s.173), Robert Koleji'nde savaş sebebiyle s1nava giremeyen öğrenciler için telafi sınavı yapılacağı belirtilmiştir ("Nakibüleşraf", 1211). 1930-40'larda savaşa bağlı olarak bölgede fiziksel gelişme anlamında bir duraklama yaşanmıştır (Salman, 2004, s.34). Bu yıllarda yayınlanan gazete ve dergilerde, Boğaziçi'nin azalmış nüfusunu yeniden kazandırmaya ve burayı kentin tercih edilen mekânları arasına katmaya yönelik teşvik ve uygulamalar gündeme gelmiştir (Salman, 2004, s.47). 1938 yılında Beşiktaş-Bebek arasında yapılan sahil yolu düzenlemelerinde caddenin genişletildiği ve Bebek Parkı'nın küçültüldügü görülmektedir. Bu süreçte Bebek Meydanı'na bakan pek çok yapı da yok olmuştur (Giray Küçük, 2020, s.73). 1950 sonrası Boğaziçi'nin fiziksel yapısı değişmiştir. Bu yıllarda gerçekleşen siyasi rejim değişikliği sonucu Adnan Menderes'in belediye başkanı olması ve yeni göçmenlerin yaygın isteklerinin siyasi amaç olarak kullanılmasıyla, iç göçler artmış, gecekondulaşma başlamıştır. 1950-1960 yılları arasında İstanbul'un kentsel yapılanmasında rol oynayan başlıca faktör, halka sunulan "modern kent" imgesindeki yüksek apartmanlar, geniş yollar ve arabalar olmuştur. 
Sonrasında toprak spekülasyonu başlamış, köyden kente yaşanan hızlı göçün etkisiyle de İstanbul, gecekondu kavramı ile tanışmıştır. İstanbul genelindeki bu nüfus artışı ve nüfus yapısı değişikliği Boğaziçi'nde ve Bebek'te okunmaktadır (Salman, 2004, s.48). 1981'de imar ve gecekondu affı ile yasadışı inşa edilmiş konut alanlarında yaşayan nüfus resmi olarak Boğaziçi nüfusuna katılmıştır. Getirilen imar affı bu tarihten sonra gecekondu yapımını yasaklamıştır. Bu dönemde siyasi rejim değişikliği sonucu Adnan Menderes'in belediye başkanı olması ile İstanbul'da pek çok yeni yol açılmış, bu süreçte pek çok yapı yıkılmıştır (Salman, 2004, s.55).

1980'lere kadar kentteki rantlar genellikle küçük girişimcilerin ilgi alanıyken bu yıllardan sonra büyük sermayenin de ilgi alanına girmiştir. Bu tarihte toplu konutlar ortaya çıkmıştır. Kent, bir önceki dönemdeki gibi tek tek binaların eklenmesiyle değil, kent parçalarının eklenmesiyle büyümeye başlamıştır (Tekeli, 2001, s.69-85). 1980'lerde Belediye Başkanı Dalan'ın imar operasyonları çerçevesinde planlanma büyük ölçüde dışlanmış, kent, boşluk bırakmadan yüksek yoğunluklu olarak gelişmesini sürdürmüştür (Salman, 2004, s.57). Kamu arazilerinin yeni inşaatlara açılması ve yapılanmış alanlarda sürekli artan inşaat yoğunluğu, politik partilere oy sağlamanın dışında, sorunları giderek daha çözülemez hale getirip kalıcı çözümleri engellemiştir (Kuban, 1996, s.411). Halk, giderek daha fazla tüketici olmuş ve çevre güzelliğine duyarsızlaşmıştır.

2000'li yıllarda Boğaziçi ve Bebek içerisinde yeni yapılaşmalar devam etmiştir ve günümüzde etmektedir. 21. yüzyıl, bilimsel, teknolojik ve ekonomik gelişmelerin yaşanmakta olduğu yüzyıldır.

Günümüzde Bebek'te kafeler, barlar, eğlence kulüpleri, konutlar, toplu konutlar, oteller, ofisler gibi çeşitli işlevlerde yapılar mevcuttur. Bunun yanında korunarak günümüze kadar gelmiş kültür varlığı değeri taşıyan anıtsal veya sivil mimarlık örneği yapılar da görülmektedir. Dini yapılardan, yalnız iki cami, bir Rum ve bir Fransız Kilisesi günümüze ulaşabilmiştir. Bunun sebebi, Cumhuriyet dönemi azınlık politikaları çerçevesinde gayrimüslimlerin büyük çoğunluğunun memleketlerine dönmeleri olmuştur. Yabancı okullar da aynı sebeple zamanla kapanmış olup yapıları farklı okullar tarafından kullanılmaktadır. Ulaşım yapıları, 20. yüzyıldaki planlama politikaları sonucu raylı ulaşım sistemi veya su taşıtları yerine kara ulaşımına ağırlık verilmesiyle; haberleşme yapıları ise teknolojinin ilerlemesi sonucu internet üzerinden haberleşmenin yaygınlaşmasıyla işlevlerini yitirmişlerdir. Su yapılarından, bir çeşme, sarnıç ve su terazisi kalıntıları ile kullanılan bir çeşme günümüze gelebilmiştir. Yaşam şeklinin değişmesi, refah düzeyinin artması gibi 
sebeplerle suya evde kolayca ulaşıla bilindiğinden ortak alandaki çeşmeler eski işlevini yitirmiş olup günümüzde sembolik bir anlam taşımaktadır.

\section{Değerlendirme}

16. yüzyılda Osmanlı sultanlarının sayfiye yerlerinden biri olan Bebek, bu dönemde bir yazlık saraya, 17. yüzyılda ise saray çevresinden önemli kişilerin yazlık köşklerine ve yalılarına ev sahipliği yapmıştır. Saray erkânının yaşadığı Bebek'te bu dönemlerde görkemli bir mimari oluşmuştur. Aynı yıllarda, Bebek'in komşu semtleri olan Arnavutköy ve Rumelihisarı'nda, hatta Boğaziçi genelinde de yalıların inşa edildiği bilinmektedir. 18. yüzyılın ilk çeyreğinde Bebek Mahallesi'nin kurulmasıyla bölge çoğunlukla sosyo-ekonomik düzeyi yüksek kişilere ev sahipliği yapmaktan çıkmıştır. Bu dönemde yalı mimarisinin yanı sıra, mütevazı konutlar, küçük bir cami ve hamam, mescit, çarşı gibi mahalleyi oluşturan daha minimal yapılar da yerleşime katılmıştır. Burada azalan sosyo-ekonomik düzeyin yapılara da yansıdığı görülmektedir. Komşu semtlerde mahalle oluşumu, Bebek'ten daha erken başlamıştır. 18. yüzyılda Ermeni ve Rumların da Bebek'te yer aldığı bilinmektedir (Salman, 2004). 19. yüzyılda Tanzimat'ın da etkisiyle yapı çeşitliliği artmış, yoğunlukla kullanılan yapı malzemesi değişmiş, ahşap yerine kâgir tercih edilmeye başlanmıştır. Gayrimüslimlerin yoğunlaşmasıyla yabancı okullar, kiliseler gibi büyük yapılar inşa edilmeye başlanmıştır. 20. yüzyıl başında Boğaz köylerinde, Balkan Savaşı ve onu izleyen Birinci Dünya Savaşı'nın yaşandığ 1 yıllarda yabancı nüfus azalmış, diğer Boğaz köyleri gibi Bebek de kozmopolit karakterini yitirmiştir. 20. yüzyılın ikinci yarısından sonra değişen planlama politikaları sonucu Boğaziçi genelinde olduğu gibi Bebek'te de sosyo-ekonomik düzey düşmüş, artan nüfusun talebini karşılamak amacıyla gecekondu, toplu konut gibi yapılar ortaya çıkmıştır. Günümüzde ise Bebek, eğlence hayatının önemli yerlerinden olup burada genellikle yüksek gelirli kişiler ikamet etmektedir.

\section{Sonuç}

Osmanlı devletinin, değişen dünya düzenine uyum sağlama çabaları, pek çok alanda değişikliklerin yapılmasına sebep olmuştur. Uzun yıllar Osmanlı devletine başkentlik yapmış olan İstanbul' da bu sürecin kente yansımalarından biri, farklı yapı tiplerinin ortaya çıkmasıdır. Kentler yaşayan ve gelişen 
organizmalar olarak sürekli bir değişim içindedir. İstanbul'un Boğaziçi yerleşimi ve bunun içerisinde Bebek semti de kentin dinamikleri doğrultusunda zaman içinde mekânsal olarak değişmiştir.

Bebek semti ile ilgili incelenen arşiv belgeleri sonucunda şu sonuçlara ulaşılmıştı;;

- Bebek'teki yapılar içerisinde en fazla arşiv belgesine sahip olanı, Bebek Kasrı'dır. 17. yüzyılda Osmanlı döneminin önemli yazlık kasırlarından olan Bebek Kasrı, bölgedeki ilk anıtsal yapılardan olup çok sayıda önemli uluslararası görüşmeye ev sahipliği yapmıştır. 19. yüzyılda Sultan Abdülmecid tarafından yıktırılmış olup günümüzde bahçesi, Bebek Parkı olarak kullanılmaktadır.

- 18. yüzyılda camisi, meşrutahaneleri, mektebi, hamamı ve çarşısıyla oluşturulan Bebek Mahallesi'nin bu yapıları zaman içinde yıkılmıştır. Günümüzde yalnız caminin 1912 yılında inşa edilmiş yeni hali mevcuttur. Bu yapılarla oluşturulan kent dokusu da 20. yüzyılda Başbakan Adnan Menderes döneminde değiştirilmiştir. Dolayısıyla Bebek Mahallesi'nin ilk yapıları ve bu yapılarla oluşturulan kent dokusu korunamamıştır.

- 17.-19. yüzyıllar arasında Osmanlı döneminin ileri gelenleri tarafindan konut olarak tercih edilmiş Bebek sahilindeki yalıların büyük çoğunluğu zaman içinde yıkılmış, bir kısmı yenilenmiş, boğaz silüeti sürekliliğini yitirerek değişime uğramıştır.

- 19. yüzyılda Bebek'teki eğitim yapılarının sayısı bir hayli fazladır. Arşiv belgelerinden görüldüğü üzere çoğunluğunu Fransız, Amerikan, Rum, Alman okulları gibi gayrimüslim okullarının oluşturduğu bu çeşitlilik, 20. yüzyılda benimsenen devlet politikaları sebebiyle azalmıştır.

Geçmişte barındırdığı yapı çeşitliliğine kıyasla Bebek'te oldukça az sayıda tarihi yapı korunarak günümüze gelebilmiştir. Bu bağlamda, semtin geçmişine tanıklık eden yapılardan birinin, örneğin İstanbul'un en eski ahşap yapılarından olan ve yıkılmaya yüz tuttuğu için acilen restore edilmesi gereken Kavafyan Konağı'nın, yerleşimin tarihini, yapılarını, kültürünü, yaşanmışlıklarını anlatan bir semt müzesine dönüştürülmesi, Bebek semtinin unutulan değerlerini gözler önüne serecektir. Geçmiş hakkında bilgi edinilmesi, hızlı bir değişim süreci yaşanan kentlerde, mevcut tarihi yapılara daha fazla önem verilmesine de sebep olacak, müzeler bu noktada geçmiş ile gelecek arasında bir köprü kuracaktır. Yalnız Bebek'te değil, tüm tarihi değer taşıyan yerleşimlerde semt müzelerinin çoğalması, geçmişini bilen ve ona sahip çıkan bir toplumun oluşmasının ilk adımları olacaktır. 


\title{
Extended Abstract
}

\section{Bosphorus Bebek District's History and Buildings}

\author{
* \\ Sezgi Giray Küçük \\ ORCID: 0000-0002-4556-4331
}

Located on the European side of Istanbul, Bebek neighborhood of Beşiktaş district is located on the Bosphorus coast. It is thought to be one of the small fishing villages established on the shores of the Bosphorus during the Byzantine period. During the Ottoman period, the first settlement here began after the conquest of Istanbul, when Bebek Çelebi, the head of the janissary chief, was in charge of the construction of the Rumeli Fortress next to Bebek, established a mansion and a garden. After the death of Bebek Çelebi, the settlement was called Bebek. Bebek became one of the Bosphorus villages preferred by the Ottoman sultans to live in the summer months, relax and have fun, and in the 16th century, the sultans had built summer mansions and gardens here. During this period, settlement in the Bosphorus was encouraged, and slow but regular population growth occurred over time. In the 16th century, Bebek Pavilion is one of the pavilions that was built during this period. Until the 19th century, the pavilion and its garden were the most important symbols of Bebek. In the palace, which is also called the conference palace, important international meetings were held in the 19th century. In the 19th century, first, the garden walls of Bebek Pavilion were demolished, then the pavillion was demolished completely by the order of Sultan Abdülmecid. Its garden was reduced in the second half of the 20th century, during the Prime Minister Adnan Menderes period, by building a road through it. The garden is used as a park (Bebek Park) today.

In 1725, Bebek Pavilion was renovated and a neighborhood was created with a mosque, housing for mosque attendants, a bazaar and a bath. In addition, the land on the shore up to the Kayalar area and on the land side belonging to the state was parceled out and sold to the people. Within a few months, a 
new Bosphorus village was established here and this village was called Hümâyun-âbâd. In addition, the name Bebek continued to be used. The bath was built in a small size. It was used by men and women at different periods. The bath was destroyed in time. Bebek Mosque was demolished in 1912 and a new mosque was built by Architect Kemaleddin. Houses for the mosque attendants and the bazaar were demolished over time due to zoning activities and do not exist today.

Many mansions were built on the Bebek coast between the 17th and 19th centuries. The majority of these mansions belong to wealthy people such as sultans, pashas, grand viziers who played a role in the administration of the state, and clergymen such as sheikh al-Islam and caliph. Most of the mansions were demolished, some were rebuilt and some were rebuilt as replicas. Kavafyan Mansion, one of the oldest wooden structures in Istanbul, built by an Armenian merchant, is in a ruined condition today, although it preserves its originality.

The 19th century is the period in which i reorganization was most intense in the Ottoman Empire. During this period, different types of buildings were built in addition to the existing ones. During this period, security buildings such as police stations, communication buildings such as telephone, telegraph, post office, transportation buildings such as tram stations and piers, entertainment buildings such as sea baths and casinos emerged in Bebek. After the declaration of the Islahat addict, non-Muslims gained many rights and foreign schools' number increased. French, Greek, German, and American schools are foreign schools in Bebek. Greek church, a synagogue, an English church, two French churches, and a monastery are non-Muslim religious buildings in Bebek. The majority of non-Muslims returned to their homeland within the framework of the minority policies of the Republican period. Foreign schools were also closed over time for the same reason and their structures are used by different schools. Today, a French school building is used by a private school, while the buildings of Robert College are used by Boğaziçi University. Transportation structures lost their functions as a result of planning policies in the 20th century, with the emphasis on land transportation instead of rail transportation system or water vehicles. Similarly, communication structures have lost their functions with the spread of communication over the internet as a result of the advancement of technology. As a result of the changing planning policies after the second half of the 20th century, the socio-economic level decreased in Bebek, as in the rest of the Bosphorus, and structures such as slums and mass 
housing emerged to meet the demand of the increasing population. Today, Bebek is home to important places of entertainment and high-income people generally live here.

Cities are in constant change as living and developing organisms. Istanbul's Bosphorus settlement and the Bebek district within it have also changed spatially over time in line with the dynamics of the city. When shedding light on the history and structures of Bebek, it is seen that quite a few historical structures have survived to the present day, compared to the variety of buildings in the past. In this context, one of the buildings witnessing the past of the district, for example, the Kavafyan Mansion, which is one of the oldest wooden structures in Istanbul and needs to be restored urgently because it is about to be demolished, is transformed into a city museum that tells the history, buildings, and culture of the settlement, will reveal Bebek district's forgotten memories and values.

\section{Kaynakça/References}

Abdullah Frères, (t.y.a). [Bebek Karakolhanesi]. Abdülhamid II, Sultan of the Turks, 18421918 Fotoğraf koleksiyonu. (Demirbaş No. F23185), IRCICA Kütüphanesi, İstanbul.

Abdullah Frères, (t.y.b). [Bebek'de Aziziye Karakolhanesi]. Abdülhamid II, Sultan of the Turks, 1842-1918 Fotoğraf koleksiyonu. (Demirbaş No. F23217), IRCICA Kütüphanesi, İstanbul.

Ağaoğlu, M. (2018). Sultan III. Mustafa ve Sultan I. Abdülhamid devri İstanbul çeşmeleri. Sosyal Bilimler Dergisi, 19, 70-115.

[Akarat defteri: Merhum Veziriazam Mesih Paşa evkafı akaratından İstanbul ve Galata'da vaki Arifzade, Kovanlı, Akseki, Sipahi gümrüğü odaları, han ile beraber sipahi gümrüğü dükkanları, Edirnekapı kurbunda Tekfur ve Kıptiler odaları, Fethiye odaları, Balat'ta haneler, Ayazma, Meyve İskelesi, Unkapanı'nda olan dükkanlar ve hanlar, Bebek Yokuşu'ndaki odalarla Galata'daki vakıf haneleri havi. a.g.tt]. (1046). Topkapı Sarayı Müzesi Arşiv Defterleri (TS.MA.d.5647), T.C. Cumhurbaşkanlığı Devlet Arşivleri Başkanlığı, Osmanlı Arşivi, Ankara.

Aksoy, E. (2015). Başlangicından günümüze Türkiye'de Fransız okulları. Synergies Turquie, $8,29-46$.

Akyüz, Y. (2012). Türk eğitim tarihi. Ankara: Pegem Akademi Yayınları.

Akyıldız, A. (2010). Şirket-i hayriyye. In İslam Ansiklopedisi. (Cilt. 39, ss. 201-203). İstanbul: Türkiye Diyanet Vakfı Yayınları.

[Alınan karardan Darüleytam Hastahanesi'ne müteallik muamelatın mekatib gibi istisnası. Bebek Darüleytamı Muallimi Sadi Bey'in maaşına zamedilen yüz kuruşun verilmesi. Müfettişliğe tayin edilen Rasim Bey'in Tedrisat Mümeyyizi Semih Bey'in vazifelerine başlama tarihinden itibaren memuriyetlerinin tasdiki. 
Darüleytam Merkez Teşkilatı'nda boşalan yerlere tayinlerin yapılmaması]. (1340). Maarif Nezareti Mektubi Kalemi (MV.223/152), T.C. Cumhurbaşkanlığı Devlet Arşivleri Başkanlı̆̆ı, Osmanlı Arşivi, Ankara.

[Asakir-i Hassa Katibi Sadi Bey'in validesine ait Bebek'teki sahilhanenin Bebek Camii musakkafatına senelik altı yüz akçe mukataa karşılığında ve içinde validesinin oturması şartıyla vakfettiği]. (1247). Hatt-1 Hümayun (HAT.1586/43), T.C. Cumhurbaşkanlığı Devlet Arşivleri Başkanlığı, Osmanlı Arşivi, Ankara.

Ayyıldız, H. R. (1961). Bebek. In İstanbul Ansiklopedisi. (Cilt. 5, ss. 2329-2330). İstanbul: Tarih Vakfi Yayınları.

Baltac, C. (2004). Mektep. In İslâm Ansiklopedisi. (Cilt. 29, ss. 6-7). İstanbul: Türkiye Diyanet Vakfi Yayınları.

Batur, A. (1985). Batılılaşma döneminde Osmanlı mimarlığı. In Tanzimat'tan Günümüze Türkiye Ansiklopedisi. (Cilt. 4, ss. 1038-1067). İstanbul: İletişim Yayınlan.

[Bebek Bahçesi'ndeki bir karakolun 1259 tarihli kitabesi]. (t.y.). Nuri Arlasez Fotoğraf Arşivi (Demirbaş No. F109877), IRCICA Kütüphanesi, İstanbul.

[Bebek Camii meşrutahanelerinin bitişiğindeki iki evin hela yolunun geçtiği yeri gösteren plan]. (t.y.). Plan-Proje-Kroki (PLK.p.00566), T.C. Cumhurbaşkanlığı Devlet Arşivleri Başkanlığı, Osmanlı Arşivi, Ankara.

[Bebek Camii müezzin-i evveline meşrut hanenin tamiri ve masrafının karşılanması]. (1314). İrade Evkaf (İ.EV.15/36), T.C. Cumhurbaşkanlığı Devlet Arşivleri Başkanlığı, Osmanlı Arşivi, Ankara.

[Bebek ecza dükkanında salgın hastalık esnasında ikamet edip fedakarlıkta bulunan Tabib Dolesb'in zaruret-i hale duçar olmasından dolayı münasib hizmette istihdam edilmesi]. (1283). Meclis-i Vala (MVL.506/4), T.C. Cumhurbaşkanlığı Devlet Arşivleri Başkanlığı, Osmanlı Arşivi, Ankara.

[Bebek Hayme Ana İnas Numune Mektebi ile Büyük Reşid Paşa ve Bayezid Zükur Numune mektepleri binalarının İstanbul Maarif Müdüriyeti'ne terki talebinin kabul olunamayacağı]. (1334). Maarif Nezareti Mektubi Kalemi (MF.MKT.1217/16), T.C. Cumhurbaşkanlığı Devlet Arşivleri Başkanlığı, Osmanlı Arşivi, Ankara.

[Bebek Karakolhanesi'ne dair]. (1282). İrade Meclis-i Vala (İ.MVL.538/ 24170), T.C. Cumhurbaşkanlığı Devlet Arşivleri Başkanlığı, Osmanlı Arşivi, Ankara.

[Bebek Karakolhanesi'nin müceddeden inşası için sarfina lüzum görülen mebaliğin Umum Jandarma ve Asakir-i Zabtiye'nin üçyüz dört senesi bütçesinde bulunan inşaat ve tamirat tertibinden tesviyesi]. (1306). İrade Dahiliye (İ.DH.1124/87852), T.C. Cumhurbaşkanlığı Devlet Arşivleri Başkanlığı, Osmanlı Arşivi, Ankara.

[Bebek karyesinde bulunan Haralambos Kilisesi'nin harap olan çan mahalinin tamirine izin verildiği]. (1307). Dahiliye Mektubi Kalemi (DH.MKT.1672/83), T.C. Cumhurbaşkanlığı Devlet Arşivleri Başkanlığı, Osmanlı Arşivi, Ankara.

[Bebek kasrı ve deniz hamamındaki bazı sandalyelerin yüzlerinin değiştirilmesine ait masraf kaydı]. (1261). Topkapı Sarayı Müzesi Arşiv Defterleri (TS.MA.d.2492), T.C. Cumhurbaşkanlığı Devlet Arşivleri Başkanlığı, Osmanlı Arşivi, Ankara. 
[Bebek Rumelihisarı'nda İngiliz cemaatine mahsus olmak üzere satın alınan arsalı hanenin yerine bir kilise inşaası]. (t.y.). Hariciye Nezareti Tahrirat (HR.TH.364/82), T.C. Cumhurbaşkanlığı Devlet Arşivleri Başkanlığı, Osmanlı Arşivi, Ankara.

[Bebek ve Rumelihisarı'nda oturan İngiliz Cemaati için Bebek'te Kilise Sokağı'ndaki ev ve arsa üzerine kilise inşaatı hususundaki ruhsat talebinin kabul edildiği. Üzüm ve meyvenin eyalet ve emaretlere geçmesine müsaade edilmediği, ancak Selanik ve Kosova üzümlerinin eyalette satilabileceğinin Bulgaristan Emareti'nce uygun bulunduğu]. (1326). Dahiliye Mektubi Kalemi (DH.MKT.1277/41), T.C. Cumhurbaşkanlığı Devlet Arşivleri Başkanlığı, Osmanlı Arşivi, Ankara.

[Bebek ve Sen Jozef Eytamhanesi'nde bulunan talebelerin açlan Darüleytam defterlerine tescilleri]. (1336). Dahiliye Sicill-i Nüfus Tahrirat Kalemi (DH.SN.THR.78/106), T.C. Cumhurbaşkanlığı Devlet Arşivleri Başkanlığı, Osmanlı Arşivi, Ankara.

[Bebek ve Yeniköy'e bir telgraf merkezi açılması]. (1286). İrade Dahiliye (İ.DH.593/41239), T.C. Cumhurbaşkanlığı Devlet Arşivleri Başkanlığı, Osmanlı Arşivi, Ankara.

[Bebek, Arnavutköyü ve Kuruçeşme'de karakol binaları inşa olunacağı]. (1259). Cevdet Askeriye (C.AS.599/25264), T.C. Cumhurbaşkanlığı Devlet Arşivleri Başkanlığı, Osmanlı Arşivi, Ankara.

[Bebek'de Alman Sefareti'nin himayesinde bulunan mektebin asli haline döndürülerek talibine satılması ve ferağ muamelesi ile ilgili hususun bildirilmesi]. (1324). Şura-yı Devlet (ŞD.2754/12), T.C. Cumhurbaşkanlığı Devlet Arşivleri Başkanlığı, Osmanlı Arşivi, Ankara.

[Bebek'de bulunan Robert Koleji'nde yapılan diploma töreninde okunan Rumca nutukun münasebetsiz olduğuna dair orada bulunan Heyet-i Teftişiye ve Muayene azasından Vekalet-i Rumiye ve Ecnebiye Müfettişi Salih tarafından verilen malumat]. (1324). Maarif Nezareti Mektubi Kalemi (MF.MKT.937/4), T.C. Cumhurbaşkanlığı Devlet Arşivleri Başkanlığı, Osmanlı Arşivi, Ankara.

[Bebek'de bulunan Soeurs de La Charite rahibelerine aid mekteb ile manastır mahallinin, mezkur rahibeler namına mukataaya rabt]. (1331). İrade Hariciye (İ.HR.431/15),

T.C. Cumhurbaşkanlığı Devlet Arşivleri Başkanlığı, Osmanlı Arşivi, Ankara.

[Bebek'de İngilizlere kilise inşa olunacak hane]. (1326). İrade Adliye ve Mezahib (I.AZN.79/24), T.C. Cumhurbaşkanlığı Devlet Arşivleri Başkanlığı, Osmanlı Arşivi, Ankara.

[Bebek'de Kayalar nam mahalde vaki Ahmed Sıdkı Efendi Mescidi'nin minaresinin tamiri ile masraflarının suret-i mahsubu]. (1311). Şura-yı Devlet (ŞD.127/32), T.C. Cumhurbaşkanlığı Devlet Arşivleri Başkanlığı, Osmanlı Arşivi, Ankara.

[Bebek'de Kovan Orfelina de Sur de Şarite rahibelerinin yetimhane, kilise, manastır, mektep ve dikişhanesi ile ilgili değerlendirmeler]. (1330). Hariciye Nezareti İstişare Odası (HR.HMŞ.IŞO.144/12), T.C. Cumhurbaşkanlığı Devlet Arşivleri Başkanlığı, Osmanlı Arşivi, Ankara.

[Bebek'de Rum milleti etfali için mekteb inşası]. (1269). İrade Hariciye (İ.HR.99/4815), T.C. Cumhurbaşkanlığı Devlet Arşivleri Başkanlığı, Osmanlı Arşivi, Ankara. 
[Bebek'de Şarite (Charite) rahibelerine ait mektep ve manastırın tashih-i kaydları]. (1906). Hariciye Nezareti İdare (HR.ID.1801/34), T.C. Cumhurbaşkanllğı Devlet Arşivleri Başkanlığı, Osmanlı Arşivi, Ankara.

[Bebek'de Tarikat-1 Kadiriyye Dergah-ı Şerifi Postnişini Abdülkadir Efendi'nin pederinden mahlul mezraadarlığın uhdesine tevcihine dair istidası]. (1282). Meclis-i Vala (MVL.480/118), T.C. Cumhurbaşkanliğı Devlet Arşivleri Başkanlı̆ı̆, Osmanl Arşivi, Ankara.

[Bebek'deki Alman Mektebi'nde tahsil etmek üzere Harput'tan gelen yirmibeş Ermeni çocuğun refaketçileri ile beraber vapurla hareket ettikleri]. (1315). Dahiliye Muamelat (DH.TMIK.M.38/31), T.C. Cumhurbaşkanlı̆̆ Devlet Arşivleri Başkanlığı, Osmanlı Arşivi, Ankara.

[Bebek'deki Fransiz müessesatından olup muvazaaten nam-1 ahara mukayyed bulunan Les Soeurs de La Charite adlı rahibelere mahsus mektep ile manastir mahallinin mezkur rahibeler, ayn yerdeki Lazarist Mektebinin ise Lazarist rahipleri namlarına kayıtlarının tashihi]. (1331). Bab-1 Ali Evrak Odası (BEO.4166/312435), T.C. Cumhurbaşkanlığı Devlet Arşivleri Başkanlığı, Osmanlı Arşivi, Ankara.

[Bebek'den Mehmed imzasiyla Malumat Risalesi'ne gönderilen telgraf mealinin, bir bilmecenin çözümünden ibaret olduğu] (1313). Maarif Nezareti Mektubi Kalemi (MF.MKT.297/19), T.C. Cumhurbaşkanlığ Devlet Arşivleri Başkanliğı, Osmanlı Arşivi, Ankara.

[Bebek-Rumelihisarı Caddesi'ndeki Hazineye ait Polis Karakolu binası arsasının bedelsiz olarak Belediye'ye devri]. (1942). Başbakanlık Kararlar Daire Başkanlığı (30-18-12/99/78/6), T.C. Cumhurbaşkanlığı Devlet Arşivleri Başkanlı̆̆ı, Cumhuriyet Arşivi, Ankara.

[Bebek'te Almanya Sefareti himayesinde bulunan inas mektebinin asli haline döndürülmesi ve talibi çıktı̆ında muamele-i ferağiyesinin ifası]. (1324). Bab-1 Ali Evrak Odası (BEO.2911/218254), T.C. Cumhurbaşkanlığı Devlet Arşivleri Başkanlığı, Osmanlı Arşivi, Ankara.

[Bebek'te bulunan Sultan Birinci Ahmed Camii'nin altındaki ibtidai mektebi ile sahil arasındaki arsaya cami imamı tarafindan kahvehane ve karpuz sergisi açlmasının engellenmesi]. (1321). Maarif Nezareti Mektubi Kalemi (MF.MKT.729/23), T.C. Cumhurbaşkanlığı Devlet Arşivleri Başkanlı̆̆ı, Osmanlı Arşivi, Ankara.

[Bebek'te Fransuva'nun tasarrufundaki Fransa müessesattndan Lazarist Mektebi'nin tamiri için ruhsat talebi üzerine rüsum-ı inşaiye taleb edilip edilmeyeceğinin Divan-1 Hümayun Kalemi'nde tayini için evrakın sadarete takdim kllındığı]. (1328). Dahiliye Muhaberat-1 Umumiye İdaresi (DH.MUI.127/11), T.C. Cumhurbaşkanlığı Devlet Arşivleri Başkanlığı, Osmanlı Arşivi, Ankara.

[Bebek'te İngiliz cemaatine mahsus bir kilise inşası]. (1326). Bab-1 Ali Evrak Odası (BEO.3367/252470), T.C. Cumhurbaşkanlığı Devlet Arşivleri Başkanlığı, Osmanlı Arşivi, Ankara. 
[Bebek'te Sen Jozef binasındaki eşyaların Darüleytam Müdüriyeti'ne tesliminin tavsiye edildiği]. (1333). Maarif Nezareti Mektubi Kalemi (MF.MKT.1205/99), T.C. Cumhurbaşkanlığı Devlet Arşivleri Başkanlığı, Osmanlı Arşivi, Ankara.

[Bebek'te sütçü dükkanında Kur'an cüzleri satıldığı ihbarının, aidiyeti ve önemi nedeniyle Dahiliye Nezareti'ne bildirildiği]. (1320). Maarif Nezareti Mektubi Kalemi (MF.MKT.679/59), T.C. Cumhurbaşkanlığı Devlet Arşivleri Başkanlığı, Osmanlı Arşivi, Ankara.

[Bebek'te Yoğurthane Sokağı'ndaki Fransız müessesatından Lazarist Mektebi'nin tamiri]. (1329). Bab-1 Ali Evrak Odası (BEO.3856/289195), T.C. Cumhurbaşkanlığı Devlet Arşivleri Başkanlığı, Osmanlı Arşivi, Ankara.

[Bebek'teki Alman Mektebi'ne Erzurum'dan gönderilecek çocukların mürur tezkirelerinin verilip Almanya tebeasından Doktor Harli'nin refakatinde Dersaadet'e azimet ettikleri]. (1313). Dahiliye Şifre Kalemi (DH.ŞFR.212/111), T.C. Cumhurbaşkanlığ1 Devlet Arşivleri Başkanlığı, Osmanlı Arşivi, Ankara.

[Bebek'teki Alman Mektebi'ne Harput ve Mamuretülaziz'den Ermeni etfalinin getirildiği ve peyderpey geleceklerin beklendiği]. (1315). Dahiliye Muamelat (DH.TMIK.M.39/8), T.C. Cumhurbaşkanlığı Devlet Arşivleri Başkanlığı, Osmanlı Arşivi, Ankara.

[Bebek'teki Fransız müessesatını havi defterde mukayyed olan Lazarist Mektebi'nin tamirine ve vergiden istisnasına izin verildiği]. (1329). Dahiliye İdare (DH.ID.117/25), T.C. Cumhurbaşkanlığı Devlet Arşivleri Başkanlığı, Osmanlı Arşivi, Ankara.

[Bebek'teki Hümayun-1 Abad Camii ile bitişiğindeki dükkanların planı]. (t.y.). Plan-ProjeKroki (PLK.p.00713), T.C. Cumhurbaşkanlığı Devlet Arşivleri Başkanlığı, Osmanlı Arşivi, Ankara.

Bebek'teki kilise 49 yıllığına Süryani Katolik Cemaati'ne verildi (2018, 17 Temmuz). 3 Kasım 2021 tarihinde https://ipa.news/tr/2018/07/17/bebekteki-suryani-kilisesi/ adresinden erişildi.

[Bebek'teki peksimethanenin tamiri]. (1216). Cevdet Askeriye (C.AS.645/27153), T.C. Cumhurbaşkanlığı Devlet Arşivleri Başkanlığı, Osmanlı Arşivi, Ankara.

Beşiktaş İlçesi Korunması Gerekli Taşınmaz Kültür ve Tabiat Varlıkları Envanteri. (2014). İstanbul: Beşiktaş Belediyesi Plan ve Proje Müdürlüğü.

[Beşiktaş-Bebek Bahçesinde Valide Hidiv sahilhanesi arazisindeki tarik kısmının krokisidir.]. (t.y.). Haritalar Koleksiyonu (Demirbaş No. Hrt_007084/01). İBB Atatürk Kitaplı̆̆ı, IBBB Kütüphaneleri, İstanbul.

[Beşiktaş-Bebek Bakkal Kilise, Hamam ve Fransız Mektebi sokakları planıdır.]. (1329). Haritalar Koleksiyonu (Demirbaş No. Hrt_004010). İBB Atatürk Kitaplı̆̆ı, İBB Kütüphaneleri, İstanbul.

[Beşiktaş-Bebek caddesinde Bebek bahçesinden Küçük Bebeğ’e kadar giden tarikin sahil kısmının arsalarının derinliği vüsati itibariyle rabian tecavüz etmeyen arsalardan matut ve karşının henüz mahalleye inkılap etmemiş araziden olmasına nazaran istikametin o cihetle yani hem istikametinin temin edilmiş olduğu ve hem de vasi- 
i araziden olmasına göre rabiine tecavüz eden arsalardan olduğundan ol-vechile lieceli't-tastik 1:500 mikyaslı haritadır.]. (1927). Haritalar Koleksiyonu (Demirbaş No. Hrt_007000). İBB Atatürk Kitaplığı, İBB Kütüphaneleri, İstanbul.

[Beşiktaş-Bebek harik mahallinin tanzim olunan haritası üzerine tayin ve tastik olunan istikamet haritasından dolayı istimlakı iktiza eden bir adet dükkan arsasıyla parke kaldırımlarının bir cihetinin istikamet-i hazırasını mai hatla irae etmek üzere harita-i musaddakadan ihraç olunan kopyasıdır.]. (1320). Haritalar Koleksiyonu (Demirbaş No. Hrt_006995). İBB Atatürk Kitaplığı, İBB Kütüphaneleri, İstanbul.

[Beşiktaş-Bebek vapur iskelesinden Akıntı Burnu'nda kain Sultan Saray-1 Alisine kadar olan tarikin istikametiyle beyninde vuku bulan iki parça harik mahallini irae eder surette tanzim kılınan haritadır.]. (1320). Haritalar Koleksiyonu (Demirbaş No. Hrt_005325). İBB Atatürk Kitaplığı, İBB Kütüphaneleri, İstanbul.

[Beşiktaş-Bebek ve civarı haritasıdır.]. (1929). Haritalar Koleksiyonu (Demirbaş No. Hrt_006998). İBB Atatürk Kitaplığı, IBBB Kütüphaneleri, İstanbul.

[Beşiktaş-Küçük Bebek meydanı-Bebek bahçesi istikamet haritasıdır.]. (1330). Haritalar Koleksiyonu (Demirbaş No. Hrt_004081). İBB Atatürk Kitaplığı, İBB Kütüphaneleri, İstanbul.

[Beykoz'da bulunan Yeni Çiftlik'te ikamet eden Fransız rahibin, Bebek'teki Fransız Kilisesi'nden talimat almadıkça çiftliğin tahriri ve arazisinin ölçümüne muvafakat etmeyeceğini söylediği]. (1866). Hariciye Nezareti Tahrirat (HR.TH.5/52), T.C. Cumhurbaşkanlığı Devlet Arşivleri Başkanlığı, Osmanlı Arşivi, Ankara.

[Boğaziçi Bebek'te Köyiçi sokağında bulunan Rum mektebinin emr-i aliye rabt1]. (1338).

Şura-yı Devlet (2840/37), T.C. Cumhurbaşkanlığı Devlet Arşivleri Başkanlığı, Osmanlı Arşivi, Ankara.

Cantay, T. (1999). Türk şehirciliğinin önemli yapıları: Su terazileri. Erdem, 12(34), 74-81.

Çelik, Z. (1996). Değişen İstanbul 19. yüzyılda Osmanlı başkenti. İstanbul: Tarih Vakfı Yurt Yayınları.

Çiftçi, A. (2001). Karakol. In İslâm Ansiklopedisi. (Cilt. 24, ss. 431-434). İstanbul: Türkiye Diyanet Vakfi Yayınları.

[Darüleytam Bebek şubesinin tesisi esnasındaki inşaa ait keşf-i sani defterinin gönderilmesi]. (1318). Maliye Nezareti Emlak-i Emiriyye Müdüriyeti, (ML.EEM.1318/6), T.C. Cumhurbaşkanlığı Devlet Arşivleri Başkanlığı, Osmanlı Arşivi, Ankara.

[Dersaadet Bebek'deki Alman Mektebi'nde okumak üzere Harput'dan Canik'e gelen Ermeni çocuklarının Rusya Kumpanyasi'nın Nahihof ve Pake Kumpanyası vapurları ile Canik'ten hareket ettikleri]. (1315). Dahiliye Muamelat (DH.TMIK.M.38/7), T.C. Cumhurbaşkanlığı Devlet Arşivleri Başkanlığı, Osmanlı Arşivi, Ankara.

Deleon, J. (1998). Boğaziçi gezi rehberi. İstanbul: Remzi Kitabevi.

Dişören, N. E. (1995). Kayalar mescidi ve tekkesi. Dünden bugüne İstanbul Ansiklopedisi. (Cilt. 4, ss. 498-499). İstanbul: Tarih Vakfi Yayınları.

Egemen, A. (1993). İstanbul'un çeşme ve sebilleri. İstanbul: Arıtan Yayınları. 
Eldem, S. H. (1979). Boğaziçi anıları. İstanbul: Alarko Eğitim Tesisleri A.Ş.

Eldem, S. H. (1993). Boğaziçi yalıları I Rumeli yakası. İstanbul: Vehbi Koç Vakfı Yayınları.

[Eminönü-Eyüb ile Ortaköy-Bebek tramvay hattının yapımına başlanması]. (1925). Nafia Vekaleti (230-0-0-0.94/37/1), T.C. Cumhurbaşkanlığı Devlet Arşivleri Başkanlığı, Cumhuriyet Arşivi, Ankara.

Envanter, (t.y.a). Bebek iskelesi. 6 Nisan 2020 tarihinde http://www.envanter.gov.tr/anit/index/detay/49252 adresinden erişildi.

Envanter, (t.y.b). Kayalar mescidi. 6 Nisan 2020 tarihinde www.envanter.gov.tr/anit/index/detay/43552 adresinden erişildi.

Eren, N. (1944). Türk Milli Eğitiminde yabancı okullar. (Yayımlanmamış yüksek lisans tezi). İstanbul Üniversitesi, İstanbul.

Ergin, O. N. (1940). Türkiye maarif tarihi 1. ve 2. cilt. İstanbul: Eser Matbaacllı.

Erkan, P. (2001). Tanzimat'tan günümüze İstanbul/Kadıköy ve Üsküdar'daki yabancı okullar ve azınlık okulları. (Yüksek lisans tezi). YÖK veri tabanından erişildi (101462).

Erdenen, O. (1994). Boğaziçi sahilhaneleri. İstanbul: Büyük Şehir Belediyesi Kültür İşleri Daire Başkanlığı Yayınları, No.12.

[Ermeni meseleleri hakkında, Bebek'deki Robert College müdürünün Ruscuk'ta Sobranya Meclisi Reisi Mösyö Todorof ile vukubulan mülakatına dair.]. (1313). Yıldız Hususi maruzat, (Y.A.HUS.338/39), T.C. Cumhurbaşkanlığı Devlet Arşivleri Başkanlığı, Osmanlı Arşivi, Ankara.

Eyice, S. (1992). Beyhan Sultan çeşmesi. In İslâm Ansiklopedisi. (Cilt. 6, ss. 65). İstanbul: Türkiye Diyanet Vakfi Yayınları.

Eyice, S. (1976). Bizans devrinde Boğaziçi. İstanbul: Edebiyat Fakültesi Basımevi.

[Fransa Devleti tebaasından Mösyö İpolit Galavani'nin Alber Galavani'nin Kandilli'deki kayıkhanesinde bulunan ve iki yıl önce el konularak Bebek Darüleytamı'na getirilen motorbotun akibetinin araştırllp neticenin bildirilmesi]. (1243). Maarif Nezareti Mektubi Kalemi (MF.MKT.1243/11), T.C. Cumhurbaşkanlığı Devlet Arşivleri Başkanlığı, Osmanlı Arşivi, Ankara.

[Fransa müessesatından Bebek'te bulunup muvazaaten nam-1 ahara mukayyed olan Sieur de La Charitee Mektebi rahiplerine mahsus mektep ile manastir mahallinin mezkur rahipler namina Lazarist Mektebi'nin de Lazarist rahipleri namina tashihi kaydları ile mukataaya rabtı hakkındaki ilamın irsali]. (1331). Şura-yı Devlet (ŞD.2382/19), T.C. Cumhurbaşkanlığı Devlet Arşivleri Başkanlığı, Osmanlı Arşivi, Ankara.

[Fransız müessesatından Bebek'te bulunup muvazaaten nam-1 ahara mukayyed olan Sör Dölaşarine Rahibeleri'ne mahsus mekteb ile manastır mahallinin mezkur rahibeler namina ve Lazarist Mektebi'nin de Lazarist Rahibleri namina tashih-i kayıtları ile mukataaya rabtı hakkındaki ilamın görülen lüzuma mebni iadesi lüzumu]. (1330). Şura-yı Devlet (ŞD.197/12), T.C. Cumhurbaşkanlığı Devlet Arşivleri Başkanlığı, Osmanlı Arşivi, Ankara.

[Galata, Beyoğlu, Beşiktaş, Ortaköy, Kuruçeşme, Bebek, Emirgan, Sarıyer, Beykoz, Kuzguncuk vs. mahallerdeki meygedelerden alınan aylık rüsumatı gösterir 
defter]. (t.y.). Bab-1 Defteri Zecriye Rüsumu defterleri (D.BŞM.ZCR.d.20524), T.C. Cumhurbaşkanlığı Devlet Arşivleri Başkanlığı, Osmanlı Arşivi, Ankara.

Galitekin, A. N., Ayvansarayî Hüseyin Efendi, Ali Satı Efendi ve Süleyman Besim Efendi (2001). Hadikatü'l-Cevami: İstanbul camileri ve diğer dini-sivil mimari yapılar. İstanbul: İşaret Yayınları.

Germiyanoğlu, C. (1961). Bebek. In İstanbul Ansiklopedisi. (Cilt. 5, ss. 2326-2330). İstanbul: Reşad Ekrem Koçu ve Mehmet Ali Akbay İstanbul Ansiklopedisi ve Neşriyat Kollektif Şirketi.

Giray Küçük, S. (2020). Bosphorus coastal road and settlements between Beşiktaş and Bebek in 1939 plan. ICONARP International Journal of Architecture and Planning, 8, 54-80. doi: https://doi.org/10.15320/ICONARP.2020.143

Gökbilgin, M. T. (1992). Boğaziçi. In İslâm Ansiklopedisi. (Cilt. 6, ss. 251-262). İstanbul: Türkiye Diyanet Vakfi Yayınları.

Göktürk, H. (1961a). Bebek camii. In İstanbul Ansiklopedisi. (Cilt. 5, ss. 2332-2333). İstanbul:

Reşad Ekrem Koçu ve Mehmet Ali Akbay İstanbul Ansiklopedisi ve Neşriyat Kollektif Şirketi.

Göktürk, H. (1961b). Bebek hamamı. In İstanbul Ansiklopedisi. (Cilt. 5, ss. 2337). İstanbul: Reşad Ekrem Koçu ve Mehmet Ali Akbay İstanbul Ansiklopedisi ve Neşriyat Kollektif Şirketi.

Güleryüz, N. (2008). Boğaziçi'nde sinagoglar ve maşatlıklar. H. Sezgin (Yay. haz.). Geçmişten Günümüze Boğaziçi içinde (ss. 369-386). İstanbul: İstanbul Büyükşehir Belediyesi Yayınları.

Gürsoy Restorasyon (t.y.). Boğaziçi Üniversitesi güney kampüs Bebek kapı köşkü. 3 Kasım 2021 tarihinde https:/gursoyrestorasyon.com.tr/projeler/bogaziciuniversitesi-guney-kampus-bebek-kapi-kosku adresinden erişildi.

[Hidivin validesinin, Bebek merkezinden çektiği telgrafların toplam ücretinin fevkalade tertibinden ödenmesi]. (1318). Dahiliye Mektubi Kalemi (DH.MKT.2457/44), T.C. Cumhurbaşkanlığı Devlet Arşivleri Başkanlığı, Osmanlı Arşivi, Ankara.

İnciciyan, P. Ğ. (1976). XVIII. astrda İstanbul. H. D. Andreasyan (tercüme ve notlar), İstanbul: İstanbul Enstitüsü Yayınları.

[İstanbul Bebek'deki Caun Chapelle Orphelinat Saint et Oeurure, des Fielos dela Charite Fransız müessesi hakkında]. (1332). Dahiliye, İdare-i Umumiye Ekleri (DH.I.UM.EK.3/110), T.C. Cumhurbaşkanlığı Devlet Arşivleri Başkanlığı, Osmanlı Arşivi, Ankara.

Kahraman, S.A ve Dağlı, Y. (2011). (Yay. haz). Günümüz Türkçesiyle Evliya Çelebi seyahatnamesi. İstanbul: Yapı Kredi Yayınları.

Kalaycl, H. (2008). Dünden bugüne Boğaziçi "Rum okulları”. Haluk Sezgin (der.), Geçmişten günümüze Boğaziçi içinde (s. 675-681). İstanbul: İstanbul Büyükşehir Belediyesi Yayınları.

Karabulut, M. (2016). Osmanlı İmparatorluğu'nda 19. yüzyılda değişim süreci, sosyal ve kültürel durum. Uluslararası Sosyal Bilimler Dergisi, 1(2), 49-65. 
Karaca, Z. (2008). İstanbul'da Tanzimat öncesi Rum Ortodoks kiliseleri. İstanbul: Yapı Kredi Yayınları.

[Kasab Andon'un eşi Korneto'nun, Bebek'deki Kasr-1 Hümayun'un yıkılarak bahçe olarak tanzimi esnasında yıkılan kasab dükkanının yeniden inşaası ve biriken kira bedelinin de tahsili talebi]. (1287). Dahiliye Mektubi Kalemi (DH.MKT.1314/24), T.C. Cumhurbaşkanlığı Devlet Arşivleri Başkanlığı, Osmanlı Arşivi, Ankara.

Kayra, C. (1993). Bebek, mekânlar ve zamanlar. İstanbul: Akbank Kültür ve Sanat Yayınları.

Kayra, C. ve Üyepazarc, E. (1992). İkinci Mahmut'un İstanbul'u, Bostancıbaşı sicilleri. İstanbul: İstanbul Büyükşehir Belediyesi Kültür İşleri Dairesi Başkanlığı Yayınları.

Koçu, R. E. (1961a). Aşiyan. In İstanbul Ansiklopedisi. (Cilt. 3, ss. 1161-1170). İstanbul: Reşad Ekrem Koçu ve Mehmet Ali Akbay İstanbul Ansiklopedisi ve Neşriyat Kollektif Şirketi.

Koçu, R. E. (1961b). Bebek bağçesi ve gazinosu. In İstanbul Ansiklopedisi. (Cilt. 5, ss. 2331). İstanbul: Reşad Ekrem Koçu ve Mehmet Ali Akbay İstanbul Ansiklopedisi ve Neşriyat Kollektif Şirketi.

Koçu, R. E. (1961c). Bebek deniz hamamları. In İstanbul Ansiklopedisi. (Cilt 5, s. 2336). İstanbul: Reşad Ekrem Koçu ve Mehmet Ali Akbay İstanbul Ansiklopedisi ve Neşriyat Kollektif Şirketi.

Koçu, R. E. (1961d). Bebek Hümayunabad kasrı. In İstanbul Ansiklopedisi. (Cilt. 5, ss. 23372339). İstanbul: Reşad Ekrem Koçu ve Mehmet Ali Akbay İstanbul Ansiklopedisi ve Neşriyat Kollektif Şirketi.

Koçu, R. E. (1961e). Bebekde Alipaşa yalısı yahud Validepaşa yalısı. In İstanbul Ansiklopedisi. (Cilt. 5, ss. 2334). İstanbul: Reşad Ekrem Koçu ve Mehmet Ali Akbay İstanbul Ansiklopedisi ve Neşriyat Kollektif Şirketi.

Koçu, R. E. (1968). Durmuş Dede tekkesi. In İstanbul Ansiklopedisi. (Cilt. 9, ss. 4770). İstanbul: Reşad Ekrem Koçu ve Mehmet Ali Akbay İstanbul Ansiklopedisi ve Neşriyat Kollektif Şirketi.

Kuban, D. (1968). Anadolu-Türk şehri tarihi gelişmesi, sosyal ve fiziki özellikleri üzerine bazı gelişmeler. Vakıflar Dergisi, 7, 53-73.

Kuban, D. (1996). İstanbul bir kent tarihi. İstanbul: Türkiye İş Bankası Kültür Yayınları.

[Mamuretülaziz'den kırkbeş yetim çocuğun, Bebek'deki Alman Mektebinde talim ve terbiye görmek üzere yola çktı̆̆1]. (1315). Dahiliye Muamelat (DH.TMIK.M.34/29), T.C. Cumhurbaşkanlığı Devlet Arşivleri Başkanlığı, Osmanlı Arşivi, Ankara.

Melling, A. I. (1819). Voyage pittoresque de Constantinople et des rives du Bosphore. Paris: Editions de Treuttel \& Würz.

[Mısır Hidivi Abbas Hilmi Paşa'nın İstanbul'a gelirken Klazomen ve Rodos'tan çektiği telgraflarla validesinin Bebek'ten çektiği telgrafların masrafının fevkalade tertibinden tesviyesine dair iradenin gereğinin yapılması]. (1323). Dahiliye Mektubi Kalemi (DH.MKT. 946/38), T.C. Cumhurbaşkanlığı Devlet Arşivleri Başkanlığı, Osmanlı Arşivi, Ankara.

[Mısır hidivi paşa hazretleriyle validesinin Bebek'ten çektikleri telgraftan eskiden olduğu gibi ücret talep edilmeyerek Mısır Telgraf İdaresi hesabına kaydedilmesi 
gerektiği]. (1326). Dahiliye Mektubi Kalemi (DH.MKT.1291/40), T.C. Cumhurbaşkanlığı Devlet Arşivleri Başkanlığı, Osmanlı Arşivi, Ankara.

[Mısır hidivi ve validesi hanımın Rodos ve Bebek merkezlerinden çektikleri telgraf ücretlerinin tesviyesi]. (1324). Bab-1 Ali Evrak Odası (BEO.2802/210082), T.C. Cumhurbaşkanlığı Devlet Arşivleri Başkanlığı, Osmanlı Arşivi, Ankara.

[Mısır Hidivinin Dersaadet'e gelirken Kılazomeş ve Rodos'dan, validesinin de Bebek merkezinden çektikleri telgrafların masraflarının irade-i seniyye mucibince fevkalade tertibinden karşılanacağının Posta ve Telgraf Nezareti'ne bildirildiği]. (1321). Dahiliye Mektubi Kalemi (DH.MKT. 801/31), T.C. Cumhurbaşkanlığı Devlet Arşivleri Başkanlığı, Osmanlı Arşivi, Ankara.

Millas, A. (1996). Sfragides Konstantinoupoleos. Athens: Enories Hagiotates Arkhiepiskopes.

Müzeler, (t.y.). Aşiyan müzesi. 3 Kasım 2021 tarihinde https:/istanbul.ktb.gov.tr/TR165467/asiyan-muzesi.html adresinden erişildi.

[Nakibüleşraf Hocazade Seyyid Ömer Efendi'nin Rumelihisarı haricinde Bebek Camii Evkafi'na mülhak Nazlıca köyündeki mescidinde imam, müezzin ve kayyumluk cihetlerinin tevcihi]. (1211). Cevdet Evkaf (C.EV.209/10434), T.C. Cumhurbaşkanlığı Devlet Arşivleri Başkanlığı, Osmanlı Arşivi, Ankara.

Nedjib (t.y.). [Guide de Stamboul, IV. Feuille partie de la Cote D'Europe 6 partie Bebek]. Haritalar Koleksiyonu (Demirbaş No. Hrt_000472). İBB Atatürk Kitaplı̆̆ı, İBB Kütüphaneleri, İstanbul.

[Ortaköy-Bebek tramvay hattı güzergahındaki yolun genişletilmesi için gerekli istimlak]. (1914). Nafia Vekaleti (230-0-0-0/93/32/4), T.C. Cumhurbaşkanlığı Devlet Arşivleri Başkanlığı, Cumhuriyet Arşivi, Ankara.

[Ortaköy-Bebek tramvay hattının çift hatta dönüştürülmesi]. (1921). Nafia Vekaleti (230-00-0.93/34/1), T.C. Cumhurbaşkanlığı Devlet Arşivleri Başkanlığı, Cumhuriyet Arşivi, Ankara.

Özel okullar rehberi. (1964). İstanbul: İskender Matbaası.

Polvan, N. (1952). Türkiye'de yabancı öğretim 1. Cilt. İstanbul: Millî Eğitim Basımevi.

Poyraz, C. ve Öztop, F. (2013). 19. yüzyılda yabancların gözüyle Osmanlı eğitimi. Eğitim ve Öğretim Araştırmaları Dergisi, 2(1), 308-316.

Prost, H. (t.y.). [Beşiktaş-Bebek imar planını gösterir haritadır. =Amenagement du Bord de Mer=Deniz kıyısı Düzenlemesi. Plan No:1428]. Haritalar Koleksiyonu (Demirbaş No. Hrt_007305). İBB Atatürk Kitaplığı, İBB Kütüphaneleri, İstanbul.

[Rumeli ciheti 87 no'lu pafta. (1926). Haritalar Koleksiyonu (Demirbaş No. Hrt_002416). İBB Atatürk Kitaplığı, İBB Kütüphaneleri, İstanbul.

[Rumeli ciheti A 19/3 no'lu pafta]. (1926). Haritalar Koleksiyonu (Demirbaş No. Hrt_002420). İBB Atatürk Kitaplı̆̆ı, IBBB Kütüphaneleri, İstanbul.

[Rumeli hisarn kurbunda Bebek karyesinde tamir ve inşa olunan peksimethane ve sair ebniyelerin kira bahasının mutasarnflarına ödenmesi]. (1214). Ali Emiri Selim III (AE.SSLM.III.331/19163) 
[Sabahaddin Beyefendi'nin riyaseti altında Bebek bahçesinde verilecek konserde Ertuğrul Korveti musikasının bulundurulması]. (1326). İrade Hususi (İ.HUS.169/41), T.C. Cumhurbaşkanlığı Devlet Arşivleri Başkanlığı, Osmanlı Arşivi, Ankara.

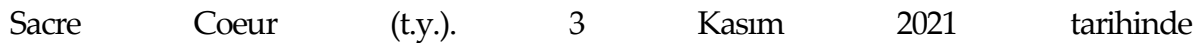
https://tr.pinterest.com/pin/393853929886380310/visualsearch/? $=16 \& y=10 \& w=530 \& h=338$ adresinden erişildi.

Salman, Y. (2004). Boğaziçi tarihi sit alanının yok olma süreci ve kalan sınırl değerlerin korunma olasılıkları. (Yayımlanmamış doktora tezi). İstanbul Teknik Üniversitesi, İstanbul.

Salman, Y. ve Kuban, D. (2006). Boğaziçi tarihi sit alanının yok oluş süreci. İTÜ Dergisi/A, 5(1), 104-114.

[Sermimaran-ı hassa Hacı Bekir Ağa marifetiyle yapılan Unkapanı, Defterdar-ı biruni, Bebek kasrı, Büyükdere, Hünkar İskelesi, Sultaniye bahçesi, Göksu kasnı ve Ayazma sarayında sandal-ı hümayun ve Ağa iskelelerinin ve Haydarpaşa ve Fenerbahçe kargir iskelelerinin ve Baltalimanı, Büyükdere, Çubuklu, Sultaniye, Göksu, Küçüksu, Haydarpaşa ve Davudpaşa sarayı ve Baruthane köprülerinin ve Dolmabahçe ve Göksu rıhtımlarının tamir ve inşa masraflarını muhtevi iskele ve köprülerin tamirat-1 masraf defteri]. (1203). Maliyeden Müdevver Defterler (MAD.d.19602), T.C. Cumhurbaşkanlığı Devlet Arşivleri Başkanlığı, Osmanlı Arşivi, Ankara.

Sezer, A. (1999). Atatürk döneminde yabancı okullar (1923-38). Ankara: TTK Basımevi.

[Sultan 2. Mahmud Evkafi'ndan Bebek'te kain cami müezzinine meşrut hanenin tesviye-i masarıfı-ı tamiriyesi]. (1314). Şura-yı Devlet (ŞD.139/34), T.C. Cumhurbaşkanlığı Devlet Arşivleri Başkanlığı, Osmanlı Arşivi, Ankara.

Şehsuvaroğlu, H. (1986). Boğaziçi'ne dair. İstanbul: Türkiye Turing ve Otomobil Kurumu Yayinları.

[Şirket-i Hayriye'nin Bebek iskelesinin merkez karyeye nakli yahut diğer bir iskelenin inşa ettirilmesi hakkında verilen arzuhal]. (1317). Bab-1 Ali Evrak Odası (BEO. 1380/103459), T.C. Cumhurbaşkanlığı Devlet Arşivleri Başkanlığı, Osmanlı Arşivi, Ankara.

[Taltifat; Şevket Bey (Darüleytam Bebek Şubesi Muallimi); Maarif Nişanı]. (1340). İrade Dosya Usulü (İ.DUIT.62/67), T.C. Cumhurbaşkanlığı Devlet Arşivleri Başkanlığı, Osmanlı Arşivi, Ankara.

Tanışık, İ. H. (1943). İstanbul çeşmeleri. İstanbul: Maarif Vekâleti.

[Taraf-ı Şahane'den Dolmabahçe'de yaptırılan yeni tüfekhane ebniyesi teferruatı masarifına karşıllk olmak üzere eski tüfekhane arsasının ve suyunun Bebek'te yanmış olan peksimethane arsasının satılması hakkındaki takririn arzı üzerine sadır olan İrade-i seniyye]. (1249). Cevdet Askeriye (C.AS. 290/12045), T.C. Cumhurbaşkanlığı Devlet Arşivleri Başkanlığı, Osmanlı Arşivi, Ankara.

Tekeli, İ. (2001). Modernite aşılırken kent planlaması, Ankara: TMMOB İmge Kitabevi.

Tekin, S. (2018). Osmanlı'nın son dönemlerinde azınlıkların yetimlerle ilgili çalışmalarından bazı örnekler ve devletin bu konuya yaklaşımı. Tarih İncelemeleri Dergisi, 33(1), 183-203. 
[Ticaret ve Nafia Nezareti Sicil Müdürü Ahmed Nedim Efendi tarafından Üsküdar'da Cemil Bey namında birine keşide olunmak üzere Bebek Telgraf Merkezi'ne tevdi ve münderecat-1 galizasından dolayı tevkif olunan ve bu sebeple muma-ileyh canibinden Telgraf ve Posta Nezareti'ne çekilen iki kıta telgrafnamenin suretlerinin gönderildiği]. (1312). Bab-1 Ali Evrak Odası (BEO.543/40691), T.C. Cumhurbaşkanlığı Devlet Arşivleri Başkanlığı, Osmanlı Arşivi, Ankara.

Yaşar, A. (2020). 1766 tarihli bir hamam defterine göre İstanbul Vakıf Hamamları. Vakıflar Dergisi, 53, 67-99. doi:https://doi.org/10.16971/vakiflar.706160

Yazıcı, N. (1985). Tanzimat döneminde Osmanlı posta örgütü. In Tanzimat'tan Cumhuriyet'e Türkiye Ansiklopedisi. (Cilt. 6, ss. 1636-1651). İstanbul: İletişim Yayınları.

Yergün, U. (2002). Batılılaşma dönemi mimarisinde yapım teknolojisindeki değişim ve gelişim. (Yayımlanmamış doktora tezi). Yıldız Teknik Üniversitesi, İstanbul.

[Yıkılmak üzre bulunan Ortaköy ve Bebek Karakolhaneleri jandarmaları için çadır verilmesi]. (1312). Yıldız Mütenevvi Maruzat (Y.MTV.99/83), T.C. Cumhurbaşkanlığı Devlet Arşivleri Başkanlığı, Osmanlı Arşivi, Ankara.

Yücel, M. S. (2016). Türkiye'de yabancı okullar ve azınlık okulları (1925-1926). (Yayımlanmamış doktora tezi). Bilecik Şeyh Edebali Üniversitesi, Bilecik.

Zamacı, A. (2009). Vilâyât-1 Sitte'de Ermeni okullanı ve faaliyetleri. Trakya Üniversitesi Sosyal Bilimler Dergisi, 11 (1), 69-85. 